\title{
Study on the practice of downhole dewaxing by in situ generated heat
}

\author{
Xinyu Mao ${ }^{1} \cdot$ Nianyin $\mathrm{Li}^{1} \cdot$ Fei Chen ${ }^{2} \cdot$ Jia Kang $^{1} \cdot$ Qian Guo $^{1} \cdot$ Peihong Han ${ }^{1}$
}

Received: 5 November 2020 / Accepted: 8 March 2021 / Published online: 31 March 2021

(c) The Author(s) 2021

\begin{abstract}
In situ heat systems are a technology that effectively solves paraffin deposition and improves oil recovery. Generally, the oxidation-reduction reaction of sodium nitrite and ammonium chloride generates a large amount of heat to promote the melting of paraffin. An in situ heat system combined with an acid-resistant fracturing fluid system can form an in situ heat fracturing fluid system, which solves the problem of the poor reformation effect caused by cold damage during the fracturing process of low-pressure and high-pour-point oil reservoirs. In this paper, with the goals of system heating up to $50{ }^{\circ} \mathrm{C}$, a low $\mathrm{H}^{+}$concentration, a high exotherm, and reduction of the toxic and harmful by-product $\mathrm{NO}_{\mathrm{X}}$, the preferred in situ heat system was found to comprise $1.6 \mathrm{~mol} / \mathrm{L}$ ammonium chloride, $1.0 \mathrm{~mol} / \mathrm{L}$ sodium nitrite, and $0.8 \%$ hydrochloric acid. The effect of five factors on the heat production of the reaction was studied experimentally, and a reaction kinetic equation for the in situ heat system was proposed based on the results. The results showed that increasing the concentration of the reactants and lowering the ambient temperature produced more heat. The in situ heat system was used to conduct a crude oil cold damage elimination experiment, and the results of the removal experiments verified that the system could effectively but not completely reduce the cold damage. Overall, the in situ heat fracturing fluid system formed by the preferred in situ heat system combined with an acid-resistant fracturing fluid system could avoid cold damage in the formation during construction and increase the output.
\end{abstract}

Keywords High-pour-point oil $\cdot$ Cold damage $\cdot$ In situ heat system $\cdot$ Heat generation law $\cdot$ Kinetic

\section{Introduction}

With the continuous exploitation of oil, conventional oil reserves are gradually decreasing, and the development of high-wax and heavy oil reservoirs has been receiving more attention. However, the process of oil and gas exploitation is often accompanied by formation or pipeline blockage due to wax and heavy oil condensation, which reduces the economic benefits of oilfield development (Goenka et al. 2014). Presently, formation stimulation treatments, including

Nianyin Li

linianyin@swpu.edu.cn

Xinyu Mao

2404083653@qq.com

1 State Key Laboratory of Oil and Gas Reservoir Geology and Exploitation Engineering, Southwest Petroleum University, Xindu District, Chengdu City 610500, Sichuan, China

2 Changqing Downhole Technical Service Company of Chuanqing Drilling Engineering Co., Ltd., CNPC, Xi'an, Shanxi, China paraffin solvent and inhibitor injection (McSpadden et al. 1986) and steam injection mining (Matus and Mamora 2005), have a short effect time, low economic yield, and certain limitations. For example, the injection of paraffin solvents and inhibitors poses HSE hazards, the cost of steam injection is high, and the injection of strong, high-temperature alkali vapors can cause reservoir damage. In situ heat measures can better adapt to this type of problem by heating the reservoir and surface production equipment to unblock them and extending the time until the next unblocking operation (Jamaluddin et al. 1996; Jamaluddin 2000).

In situ heat systems have become an effective technology to improve oil recovery and reservoir reconstruction (Davies et al. 1981). Presently, common systems include ammonium salt and nitrite heat systems and hydrogen peroxide heat systems. The ammonium and nitrite in the former undergo an exothermic chemical reaction under the action of a catalyst to generate nitrogen gas, which releases a large amount of heat to heat the reservoir around the wellbore and melt the paraffin deposited in the tubing and reservoir. The hydrogen peroxide in the latter releases a large amount of heat 
and oxygen; however, $\mathrm{H}_{2} \mathrm{O}_{2}$ has strong oxidizing properties. As its concentration increases, its activity increases; a large amount of oxygen is generated after decomposition, and the safety hazard grows (Bayless 1997).

The most widely used in situ heat system is composed of sodium nitrite and ammonium chloride. It has achieved good results in paraffin deposit removal (Qamruzzaman et al. 2020; Meagan et al. 2018; Al-Yaari 2011), heavy oil production promotion (Olalekan 2019; Al-Nakhli et al. 2016), reservoir reconstruction (Zhang et al. 2020), hydrate production promotion (Denney 2008; Evangelista et al. 2009; Demirbas 2010; Feng et al. 2018; Li et al. 2015; Song et al. 2016; Wang et al. 2014; Li et al. 2018), condensate removal in condensate reservoirs (Hassan et al. 2019a, b), and removal of emulsion blockages caused by oil-based mud (Olalekan 2020). Reconcavo Basin wells in NE Brazil, $X$ field in western India, 174 fields in South Marsh Island, Fruitvale field in California, USA, and NPR 3 field in Casper, Wyoming, all have good effects for paraffin removal (Nelson et al. 2003; Mitchell et al. 1984). The in situ heat systems used in oil fields in Saudi Arabia, Malaysia, West Texas, and Kansas have shown good heat generation and plug removal effects (Al-Taq et al. 2014; Saidu Mohamed 2013). Adding an in situ heating system to fracturing and acidification working fluid can also solve the problem of cold damage to the fluid, which solves the problem of working fluid cold injury in $\mathrm{X}$ field in northwestern India and a field in northeast Brazil (Tiwari et al. 2014; Khalil et al. 1990; Shaoul et al. 2009). Moreover, adding emulsifiers and paraffin solvents to an in situ heat system can promote paraffin dissolution and has a good effect on the removal of paraffin deposits from ground equipment and pipelines. The Gulf of Mexico uses an in situ heat system to remove paraffin deposits from ground equipment and pipelines to obtain economic benefits (Rollins and Taylor 1959; Collesi et al. 1987).

Targeting the cold damage of wax deposition as a research target, Xie has used crude oil to damage a core to simulate cold damage of a reservoir and found that the results of such damage are irreversible (Xie 2020). Amjed Hassan has introduced an in situ heat system in tight and low-permeability reservoirs and quantified the effect of thermochemical treatment on improving the productivity of low-permeability water plugging cores (Hassan et al. 2019a, b). Via a core experiment, Amjed Hassan has also found that an in situ heat system can effectively improve the flow conditions of shale through heat generation and gas production (Hassan et al. 2020). Through various experiments and kinetic studies, Felipe has demonstrated the law of nitrite and $\mathrm{H}^{+}$concentration on the formation of $\mathrm{NO}_{\mathrm{X}}$ in reaction systems and found that high concentrations of both will increase the systems' heat generation while simultaneously producing more brown-red gaseous $\mathrm{NO}_{\mathrm{X}}$, which is harmful to the environment and biological health (Felipe 2019). Ashton believed that there is an optimal catalyst concentration based on $\mathrm{pH}$ value and that the concentration range should ensure that the system $\mathrm{pH}$ value is between 5.0 and 8.0 ; the reaction rate is largest when the $\mathrm{pH}$ value is 5.0 and smallest when the $\mathrm{pH}$ value is 8.0 (Ashton et al. 1989). Cheng has combined an in situ heat system with autogenous acid to conduct an experimental study on the gas production of in situ heat systems, deriving the system's reaction kinetic equation based on the gas production (Cheng et al. 2019).

This paper aims to study the influence of several reaction parameters (i.e., type and concentration of heat-generating agent, type and concentration of catalyst, and ambient temperature) on the heat-generating capacity of a heat-generating system of sodium nitrite and ammonium chloride. A kinetic study based on the heat generation of the system is conducted. With the goals of heating up to $50{ }^{\circ} \mathrm{C}$ and reducing the by-product $\mathrm{NO}_{\mathrm{X}}$, a heat-generating formula with a low $\mathrm{H}^{+}$concentration is proposed. This in situ heat system is combined with hydrophobic polymer fracturing fluid to form an in situ heat fracturing fluid system with effective cross-linking and complete gel breaking. High-pour-point oil is used to displace the formation core to simulate formation cold damage, and then, the optimized in situ heat system is introduced to remove the cold damage. The system's effect is analyzed from the perspective of macroscopic permeability changes and scanning electron microscope images. Overall, in low-pressure reservoirs containing high-pour-point oil, the use of in situ heat fracturing fluid for reservoir reconstruction compared with conventional fracturing fluid systems could effectively avoid cold damage and improve the effect of stimulation.

\section{Experimental materials and methods}

\section{Experimental materials and instruments}

\section{Experimental materials}

The chemicals used in this study included sodium nitrite $\left(\mathrm{NaNO}_{2}\right)$, ammonium chloride $\left(\mathrm{NH}_{4} \mathrm{Cl}\right)$, hydrochloric acid $(37 \% \mathrm{HCl})$, sulfamic acid $\left(\mathrm{NH}_{2} \mathrm{SO}_{3} \mathrm{H}\right)$, citric acid $(\mathrm{CA})$, and urea $\left(\mathrm{CH}_{4} \mathrm{~N}_{2} \mathrm{O}\right)$; these chemicals were purchased from Sinochem Reagent Co., Ltd. Distilled water was used to dissolve the above compounds. The study also used a certain reservoir waxy crude oil, artificial sandstone core (a certain reservoir sandstone powder was used to make the core; core permeability: $38.8 \mathrm{mD}$, core radius: $1.26 \mathrm{~cm}$, and length: $6.98 \mathrm{~cm}$ ), and N80 standard corroded steel sheets. 


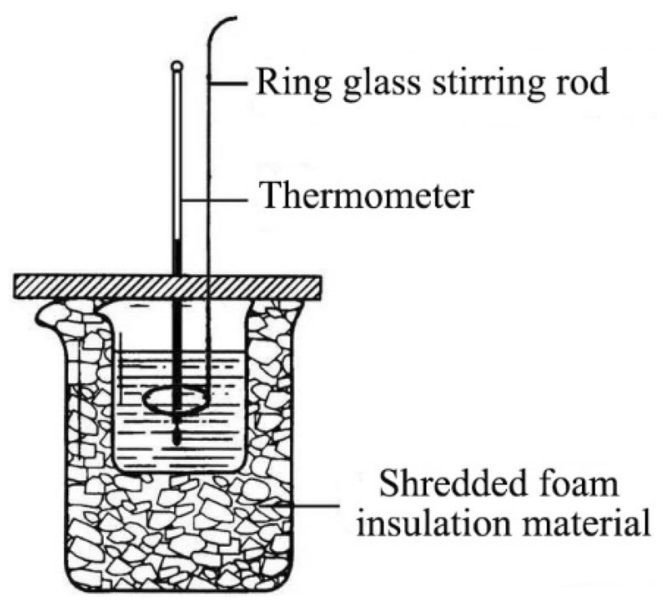

Fig. 1 Self-made airtight heat preservation container

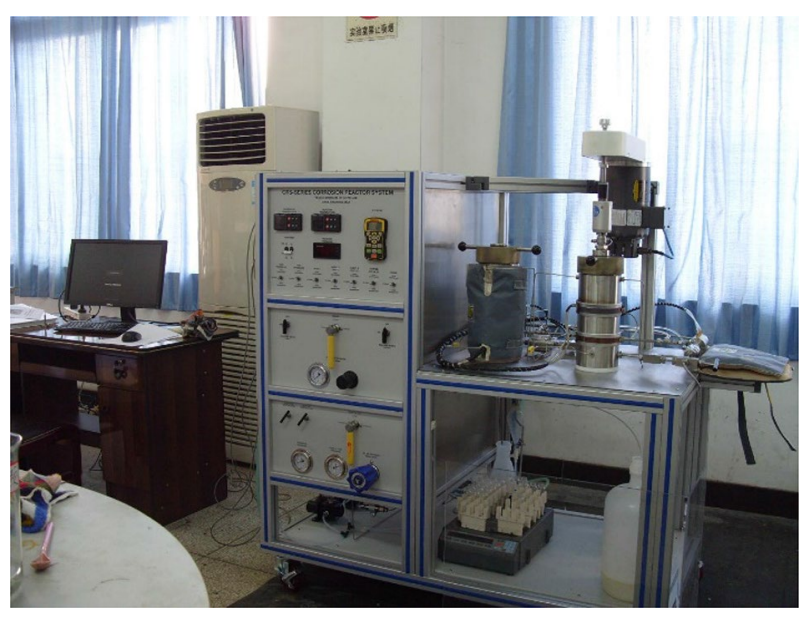

Fig. 2 Rotating disk apparatus

\section{Experimental instruments}

In this study, a self-made airtight heat preservation container was used; as Fig. 1 shows, the objective of measuring accurate temperature values was achieved using heat preservation materials to isolate the reaction container from contact with the air. A rotating disk apparatus (Fig. 2), core flooding device (Fig. 3), gas chromatograph, rheometer, and water bath were also used.

\section{Experiment}

\section{Performance evaluation of in situ heat system and optimization of heat-generating agent}

Peak temperature At a room temperature of $20{ }^{\circ} \mathrm{C}$, a control experiment was performed to analyze the relationship between the peak temperatures of the two types of in situ

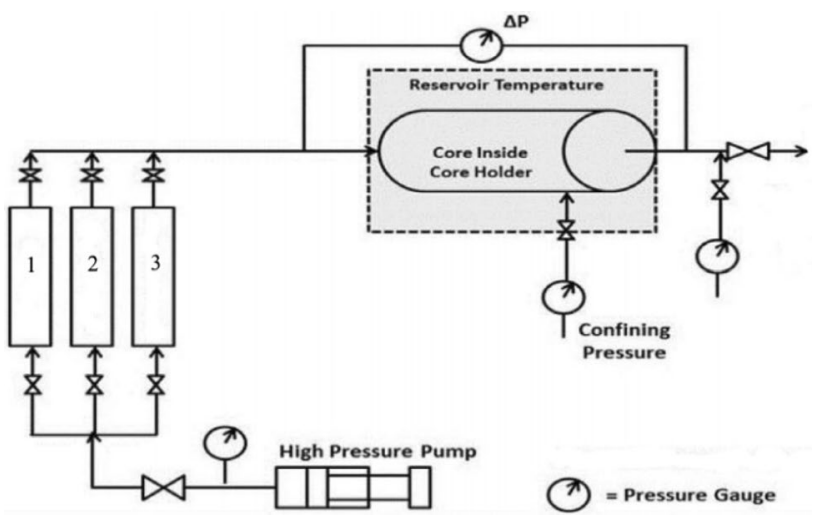

Fig. 3 Core flooding device

Table 1 Relationship between reactant concentration and peak temperature in system A

\begin{tabular}{lll}
\hline $\begin{array}{l}\text { Reactant concentration } \\
(\mathrm{mol} / \mathrm{L})\end{array}$ & Peak temperature $\left({ }^{\circ} \mathrm{C}\right)$ & $\begin{array}{l}\text { Arrival } \\
\text { time } \\
(\mathrm{min})\end{array}$ \\
\hline 1.0 & 55 & 10 \\
1.5 & 68 & 10 \\
2.0 & 75 & 9 \\
2.5 & 86 & 6 \\
3.0 & 90 & 2 \\
\hline
\end{tabular}

heat systems and the changes in the concentrations of the reaction components. Here, 10 concentration control groups were set, with a concentration gradient of $0.5 \mathrm{~mol} / \mathrm{L}$ and a concentration range of $1-3 \mathrm{~mol} / \mathrm{L}$. Then, $2 \% \mathrm{HCl}$ was selected for the in situ heat system of $\mathrm{NaNO}_{2}$ and $\mathrm{NH}_{4} \mathrm{Cl}$ (system $\mathrm{A}$ ), and $\mathrm{CA}$ of the same proportion was selected for the in situ heat system of $\mathrm{NaNO}_{2}$ and $\left(\mathrm{CO}\left(\mathrm{NH}_{2}\right)_{2}\right)$ (system B). The total volume of each group's solution was $100 \mathrm{~mL}$. The temperature measurement experiment was performed in the self-made airtight heat preservation container, ${ }^{1}$ and the temperature recording was performed every minute. When the temperature began to decrease, the experiment recording was stopped. Tables 1 and 2 show the experimental results.

Gas production At a room temperature of $20^{\circ} \mathrm{C}$, system A was selected for the pressure-boosting performance test. The concentration gradient was set to $0.5 \mathrm{~mol} / \mathrm{L}$ and the concentration range to between 1 and $2.5 \mathrm{~mol} / \mathrm{L}$. The total volume of each group solution was $500 \mathrm{~mL}$. The pressure measurement experiment was performed with the rotating disk apparatus, and the pressure recording was performed

\footnotetext{
1 The self-made airtight heat preservation container used sponge and other heat-preserving materials to wrap the in situ heat reaction vessel to achieve the purpose of the heat preservation test.
} 
Table 2 Relationship between reactant concentration and peak temperature in system B

\begin{tabular}{lcc}
\hline $\begin{array}{l}\text { Reactant concentration } \\
(\mathrm{mol} / \mathrm{L})\end{array}$ & Peak temperature $\left({ }^{\circ} \mathrm{C}\right)$ & $\begin{array}{l}\text { Arrival } \\
\text { time } \\
(\mathrm{min})\end{array}$ \\
\hline 1.0 & 77 & 13 \\
1.5 & 91 & 9 \\
2.0 & 99 & 4 \\
2.5 & 112 & 4 \\
3.0 & 116 & 1 \\
\hline
\end{tabular}

Table 3 Corrosion rate of the different in situ heat systems

\begin{tabular}{llc}
\hline Different in situ heat systems & Corrosion time (h) & $\begin{array}{l}\text { Corrosion } \\
\text { rate }(\mathrm{g} / \\
\left.\left[\mathrm{m}^{2} \mathrm{~h}\right]\right)\end{array}$ \\
\hline System A & 2 & 80.42 \\
System B & 2 & 331.635 \\
\hline
\end{tabular}

every minute. When the pressure was constant, the experiment recording was stopped.

At a room temperature of $20^{\circ} \mathrm{C}, 1 \mathrm{~mol} / \mathrm{L}$ of system $\mathrm{A}$ and $1 \mathrm{~mol} / \mathrm{L}$ of system B were selected for pressure-boosting performance testing. The total volume of each group solution was $500 \mathrm{~mL}$. The pressure measurement experiment was performed with the rotating disk apparatus, and the pressure recording was performed every minute. When the pressure was constant, the experiment recording was stopped.

Causticity A total of $1 \mathrm{~mol} / \mathrm{L}$ of system A and $1 \mathrm{~mol} / \mathrm{L}$ of system $\mathrm{C}$ were selected for the corrosion performance test. The total volume of each group solution was $250 \mathrm{~mL}$. The solutions were placed in water maintained at a constant temperature of $65^{\circ} \mathrm{C}$ for 2 for the static corrosion test. The corrosion state of the in situ heat systems on an N80 steel sheet was tested, and the corrosion rate was calculated. Table 3 shows the experimental results.

\section{Study on the influence factors of heat generation of the in situ heat system of sodium nitrite and ammonium chloride}

Effect of the type of heat-generating agent on the heat generation rate The type of heat-generating agent is the key factor that determines the heat-generating performance of systems under the same environmental conditions. However, the agent's heat-generating reaction will be greatly affected by different catalysts, concentrations, ambient temperatures, and other conditions. The type of heat-generating agent was optimized to determine the basic structure of the heat-generating system.

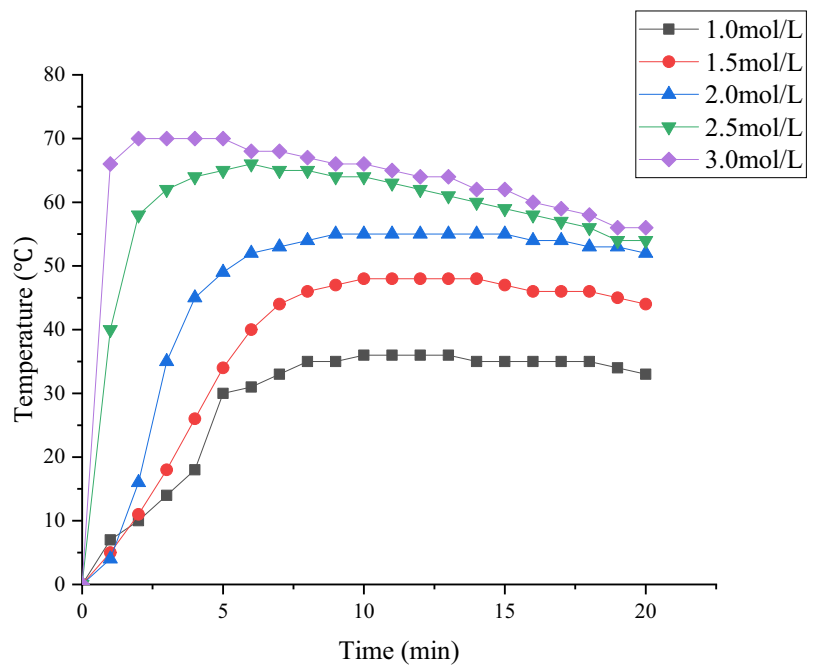

Fig. 4 Heating performance of different concentrations of $\mathrm{NaNO}_{2}$ and $\mathrm{NH}_{4} \mathrm{Cl}$

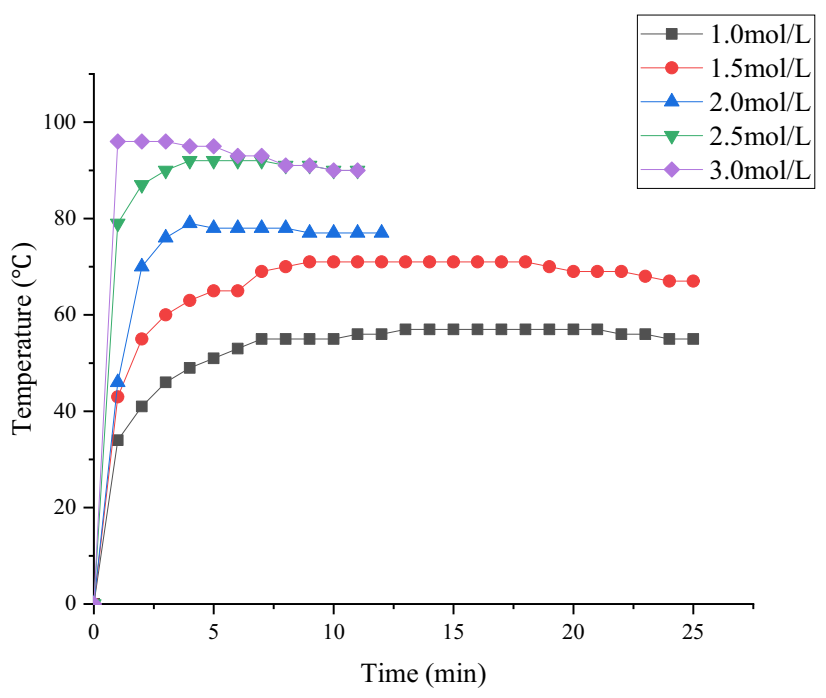

Fig. 5 Heating performance of different concentrations of $\mathrm{NaNO}_{2}$ and $\left(\mathrm{CO}\left(\mathrm{NH}_{2}\right)_{2}\right)$

At a room temperature of $20^{\circ} \mathrm{C}$, a temperature performance evaluation experiment with different concentrations of the in situ heat systems was conducted. Both system A and system $\mathrm{C}$ had a concentration gradient of $0.5 \mathrm{~mol} / \mathrm{L}$ and a concentration range of $1-3 \mathrm{~mol} / \mathrm{L}$. A total of 10 solutions comprised the control group, and the total volume of each group of solutions was $100 \mathrm{~mL}$. The temperature measurement experiment was conducted in the self-made sealed thermal insulation instrument; temperature records were taken every minute, and the recording was stopped when the temperature began to drop. Figures 4 and 5 show the experimental results. 


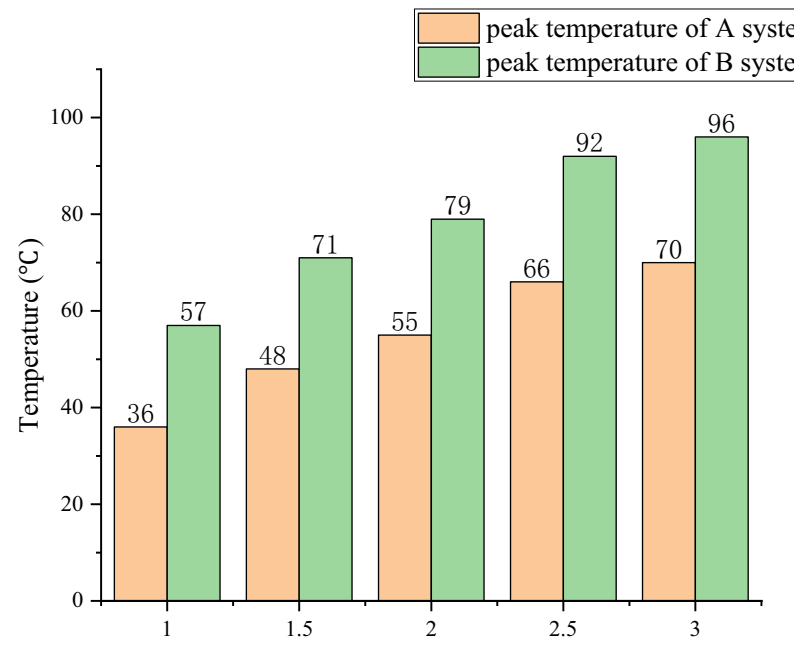

The concentration of the heat generating agent $(\mathrm{mol} / \mathrm{L})$

Fig. 6 Peak temperature of different concentrations of the heat-generating agent

Effect of the concentration of heat-generating agent on the heat generation rate The changes in the heat generation value were observed and recorded to determine the concentration changes of the heat-generating agent. According to the comparative analysis of the temperature and pressure theoretical data of the heat-generating reaction and the experimental data, it was determined that the change of the reactant concentration ratio of system A affected the heatgenerating performance. Under the relevant experimental conditions, e.g., room temperature of $20^{\circ} \mathrm{C}$, the reaction did not reach the $100 \%$ reaction degree and stayed generally below $50 \%$. The concentration of the heat-generating agent was optimized to optimize the heat generation value of the heat-generating system (Fig. 6).

(1) At a room temperature of $20^{\circ} \mathrm{C}$, the temperature rise performance of $\mathrm{NH}_{4} \mathrm{Cl}$ at different concentrations was evaluated and analyzed. The concentration of $\mathrm{NaNO}_{2}$ was $1 \mathrm{~mol} / \mathrm{L}$. Using $1 \% \mathrm{HCl}$, the effect of different concentrations of $\mathrm{NH}_{4} \mathrm{Cl}$ on the heating performance was observed. Here, 11 groups of $\mathrm{NH}_{4} \mathrm{Cl}$ solutions were set with a concentration gradient of $0.1 \mathrm{~mol} / \mathrm{L}$ and a concentration range of $1-2 \mathrm{~mol} / \mathrm{L}$. These groups were then mixed with 11 groups of $1 \mathrm{~mol} / \mathrm{L} \mathrm{NaNO}_{2}$ solution and $1 \% \mathrm{HCl}$; the total volume of each group solution was $100 \mathrm{~mL}$. The temperature measurement experiments were conducted in self-made sealed thermal insulation instruments. The temperature was recorded every minute, and the influence of the concentration of $\mathrm{NH}_{4} \mathrm{Cl}$ on the temperature performance was compared and analyzed. The experiment recording was stopped when the temperature began to drop. Figure 7 shows the experimental results.

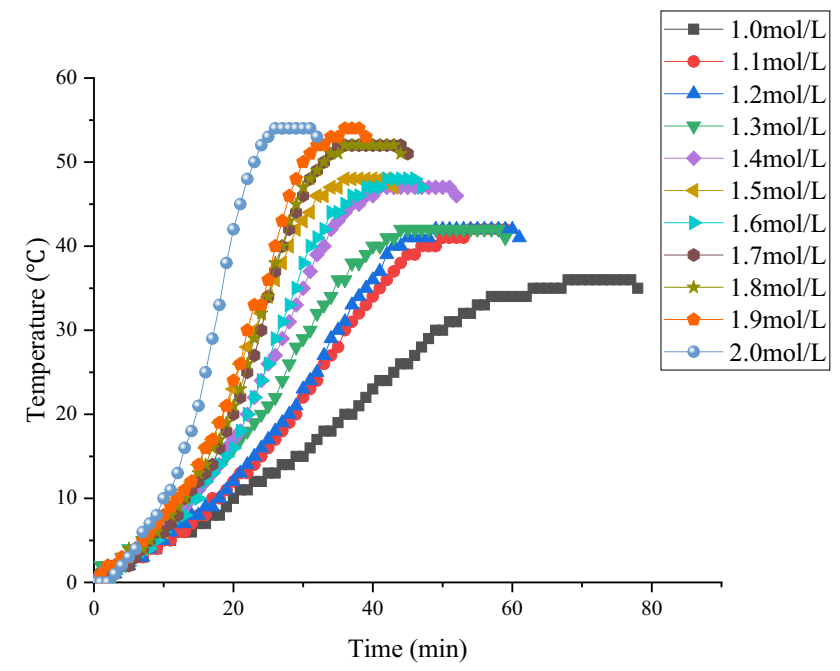

Fig. 7 The effect of different concentrations of $\mathrm{NH}_{4} \mathrm{Cl}$ on the heating performance

(2) At a room temperature of $20^{\circ} \mathrm{C}$, the temperature rise performance of $\mathrm{NaNO}_{2}$ at different concentrations was evaluated and analyzed. The $\mathrm{NH}_{4} \mathrm{Cl}$ concentration was $1 \mathrm{~mol} / \mathrm{L}$, using $1 \% \mathrm{HCl}$, and the effect of different concentrations of $\mathrm{NaNO}_{2}$ on the heating performance was observed. Here, 11 groups of $\mathrm{NaNO}_{2}$ solutions were set with a concentration gradient of $0.1 \mathrm{~mol} / \mathrm{L}$ and a concentration range of 1-2 mol/L. These solution groups were mixed with 11 groups of $1 \mathrm{~mol} / \mathrm{L} \mathrm{NH}_{4} \mathrm{Cl}$ solution and $1 \% \mathrm{HCl}$, and the total volume of each group solution was $100 \mathrm{~mL}$. The temperature measurement experiments were conducted in the self-made sealed thermal insulation instrument. The temperature was recorded every minute, and the influence of the concentration of $\mathrm{NaNO}_{2}$ on the temperature rise performance was compared and analyzed. The experiment recording was stopped when the temperature began to drop. Figure 8 shows the experimental results.

Effect of the catalyst type on the heat generation rate When various conditions are fixed, changing the type of catalyst could effectively control the system heating rate. The same initial temperature $\left(20^{\circ} \mathrm{C}\right)$ was selected for the laboratory test, allowing the heat-generating agent to react under adiabatic conditions. The relationship between the catalyst and the heat generation rate was studied and discussed by changing the type of catalyst. The type of catalyst was optimized to optimize the heat generation value of the heat-generating system.

At a room temperature of $20{ }^{\circ} \mathrm{C}$, a $100 \mathrm{~mL}$ solution comprising $1 \mathrm{~mol} / \mathrm{L}$ of $\mathrm{NaNO}_{2}$ and $2 \mathrm{~mol} / \mathrm{L}$ of $\mathrm{NH}_{4} \mathrm{Cl}$ (to ensure the maximum reaction progress) was tested for a heat

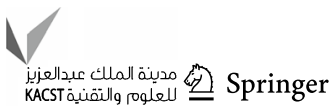




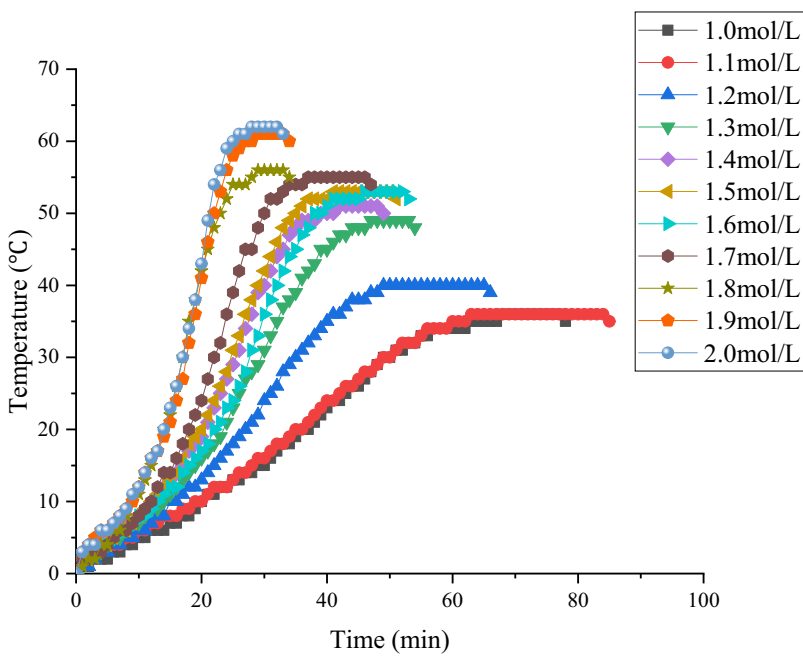

Fig. 8 The effect of different concentrations of $\mathrm{NaNO}_{2}$ on the heating performance

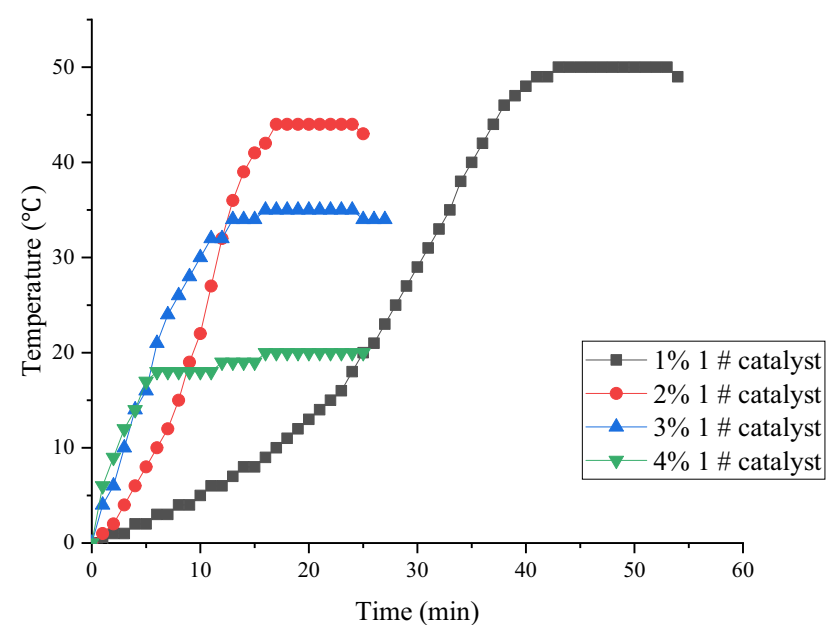

Fig. 9 Heating performance of $\mathrm{NaNO}_{2}$ and $\mathrm{NH}_{4} \mathrm{Cl}$ at different catalyst concentrations of $\mathrm{HCl}$

generation reaction. Here, $\mathrm{HCl}$, sulfamic acid, and $\mathrm{CA}$ were selected for the experiment. The concentration of each catalyst was $1 \%, 2 \%, 3 \%$, and $4 \%$. Temperature measurement experiments were conducted in the self-made sealed thermal insulation instrument. The temperature was recorded every minute, and the influence of the effect of the catalyst type on the temperature rise performance was compared and analyzed. The experiment recording was stopped when the temperature began to drop. Figures 9, 10 and 11 show the experiment results.

Effect of the catalyst concentration on the heat generation rate According to the experimental data of the catalyst optimization and the analysis of the related results, both the optimal catalyst type and optimal catalyst concentration

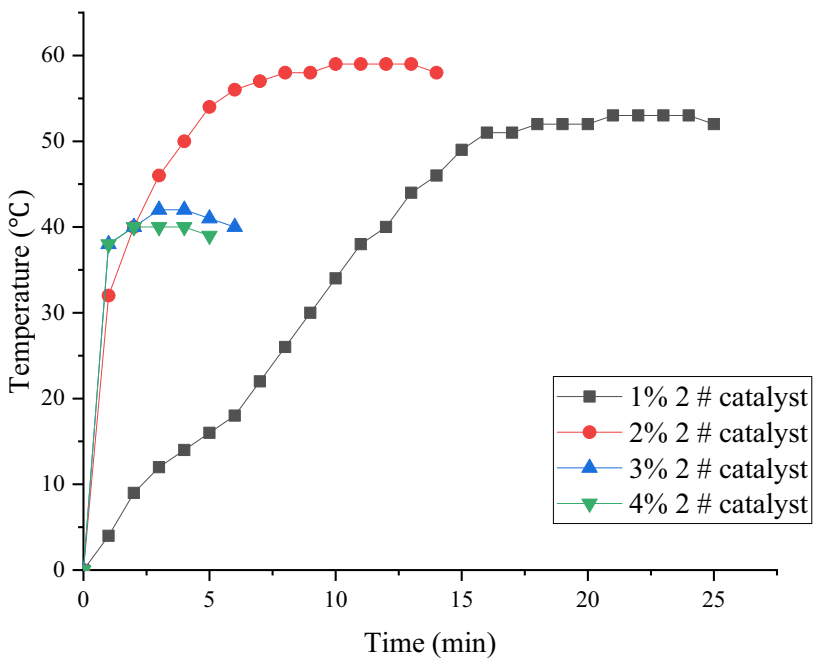

Fig. 10 Heating performance of $\mathrm{NaNO}_{2}$ and $\mathrm{NH}_{4} \mathrm{Cl}$ at different catalyst concentrations of sulfamic acid

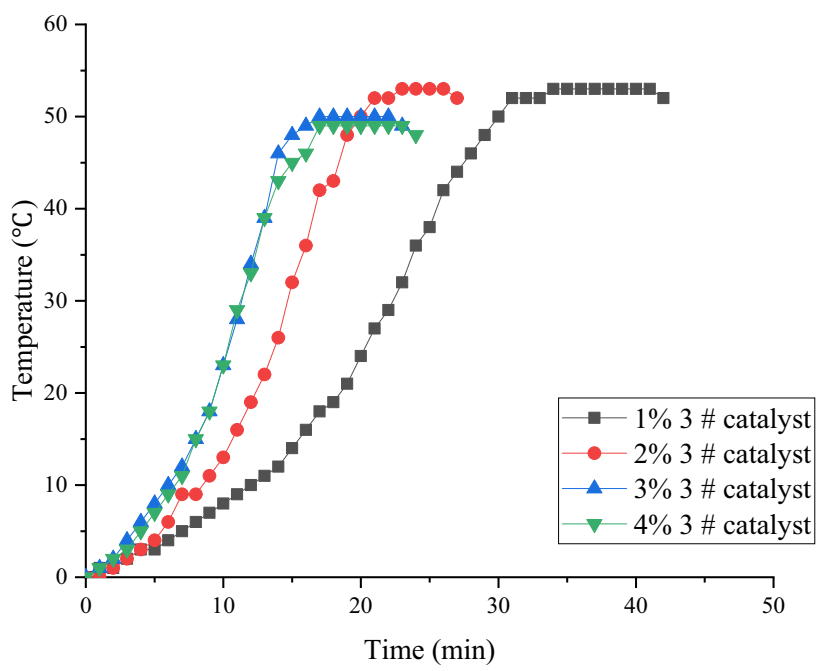

Fig. 11 Heating performance of $\mathrm{NaNO}_{2}$ and $\mathrm{NH}_{4} \mathrm{Cl}$ at different catalyst concentrations of citric acid

were determined for the in situ heat system. The changes in the heating rate and peak temperature did not have a positive correlation with the reaction rate. The catalyst concentration was optimized to optimize the heat generation value of the heat-generating system.

(1) At a room temperature of $20{ }^{\circ} \mathrm{C}$, a $100 \mathrm{~mL}$ solution comprising $1 \mathrm{~mol} / \mathrm{L}$ of $\mathrm{NaNO}_{2}$ and $2 \mathrm{~mol} / \mathrm{L}$ of $\mathrm{NH}_{4} \mathrm{Cl}$ (to ensure the maximum reaction progress) was tested for a heat generation reaction. Here, $\mathrm{HCl}$ was used in the concentration range of $0.4-2 \%$, and the concentration gradient was $0.2 \%$. The temperature measurement experiment was conducted in the self-made sealed 


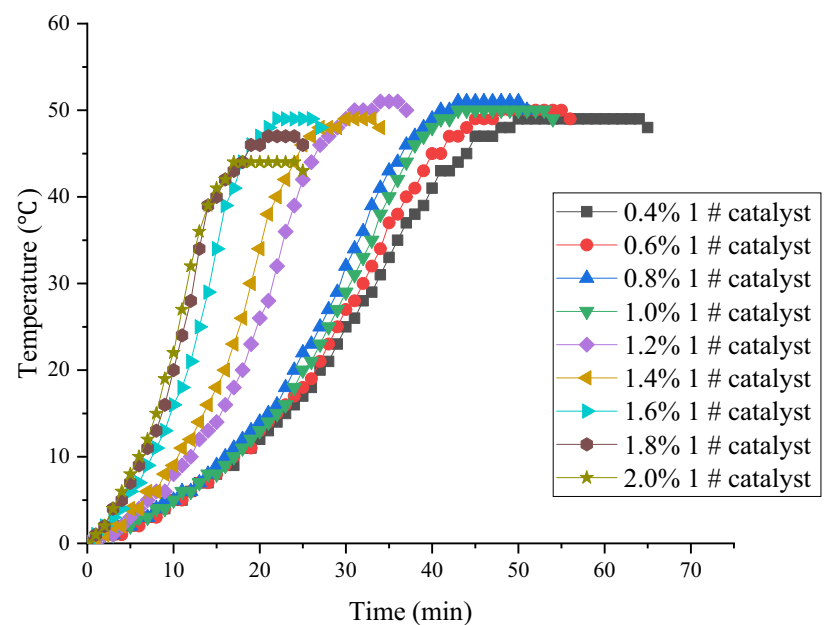

Fig. 12 Heating performance of $\mathrm{NaNO}_{2}$ and $\mathrm{NH}_{4} \mathrm{Cl}$ at different catalyst concentrations of $\mathrm{HCl}$

thermal insulation instrument. The temperature was recorded every minute, and the effect of the catalyst concentration on the temperature rise performance was compared and analyzed. The experiment recording was stopped when the temperature began to drop. The best catalyst concentration was found, and Fig. 12 shows the experimental results.

(2) According to the results of the above experiment, the optimal catalyst concentration range of this concentration of heat-generating agent was determined. At a room temperature of $20{ }^{\circ} \mathrm{C}$, a $100 \mathrm{~mL}$ solution comprising $1 \mathrm{~mol} / \mathrm{L}$ of $\mathrm{NaNO}_{2}$ and $2 \mathrm{~mol} / \mathrm{L}$ of $\mathrm{NH}_{4} \mathrm{Cl}$ (to ensure the maximum reaction progress) was tested for a heat generation reaction. Here, $\mathrm{HCl}$ was used in the concentration range of $0.6 \%-1.2 \%$, and the concentration gradient was $0.1 \%$. The temperature measurement experiment was conducted in the self-made sealed thermal insulation instrument. The temperature was recorded every minute, and the effect of the catalyst concentration on the temperature rise performance was compared and analyzed. The experiment recording was stopped when the temperature began to drop. The best catalyst concentration was found, and Fig. 13 shows the experimental results.

Effect of ambient temperature on the heat generation rate Ambient temperature is an essential factor that affects the progress of chemical reactions. Generally, a high-temperature environment will promote an endothermic reaction and increase its degree of progress but inhibit the forward progress of an exothermic reaction and reduce its degree of progress. Herein, the reaction of the in situ heat system

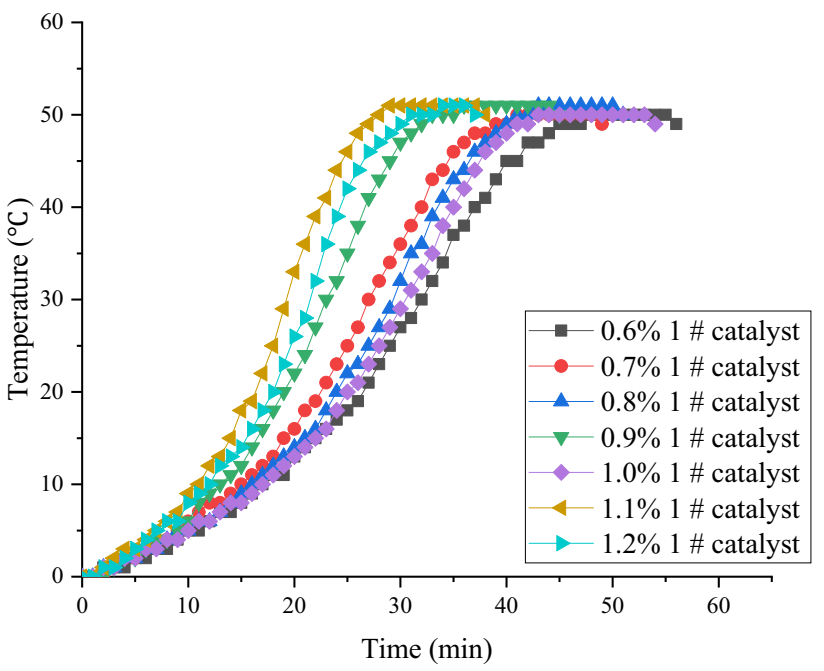

Fig. 13 Heating performance of $\mathrm{NaNO}_{2}$ and $\mathrm{NH}_{4} \mathrm{Cl}$ at different catalyst concentrations of $\mathrm{HCl}$

was exothermic, so it was speculated that as the ambient temperature increased, the peak temperature of the reaction would decrease and the heating rate would greatly increase. Six control groups with different ambient temperatures were selected for the experiment to observe the influence of the environmental temperature on the in situ heat system.

The clear water used in the experiment was heated to $10{ }^{\circ} \mathrm{C}, 20{ }^{\circ} \mathrm{C}, 30{ }^{\circ} \mathrm{C}, 40{ }^{\circ} \mathrm{C}, 50{ }^{\circ} \mathrm{C}$, and $60{ }^{\circ} \mathrm{C}$, and after the temperature stabilized, six groups of $100 \mathrm{~mL}$ solutions with different temperature gradients were prepared. The solution included $1 \mathrm{~mol} / \mathrm{L}$ of $\mathrm{NaNO}_{2}, 2 \mathrm{~mol} / \mathrm{L}$ of $\mathrm{NH}_{4} \mathrm{Cl}$ (to ensure the maximum reaction progress), and $1 \%$ of the $1 \#$ catalyst. Temperature measurement experiments were conducted in the self-made sealed thermal insulation instrument, and the temperature was recorded every minute. The effect of the ambient temperature on the temperature rise performance was compared and analyzed, and the experiment recording was stopped when the temperature began to drop. Figure 14 shows the experiment results.

\section{Experiment on in situ heat systems' ability to remove cold damage}

The cold damage of waxy high-pour-point oil was the primary problem addressed in this study. A certain reservoir containing waxy high-pour-point oil was used as the research object. Crude oil composition, wax melting point, wax precipitation point, and freezing point experiments were conducted to determine the basic physical properties of the crude oil and the experimental heat-generating agent's concentration range. The waxy high-pour-point oil from the certain reservoir was used to perform cold damage

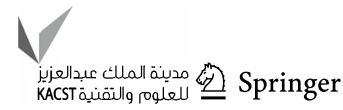




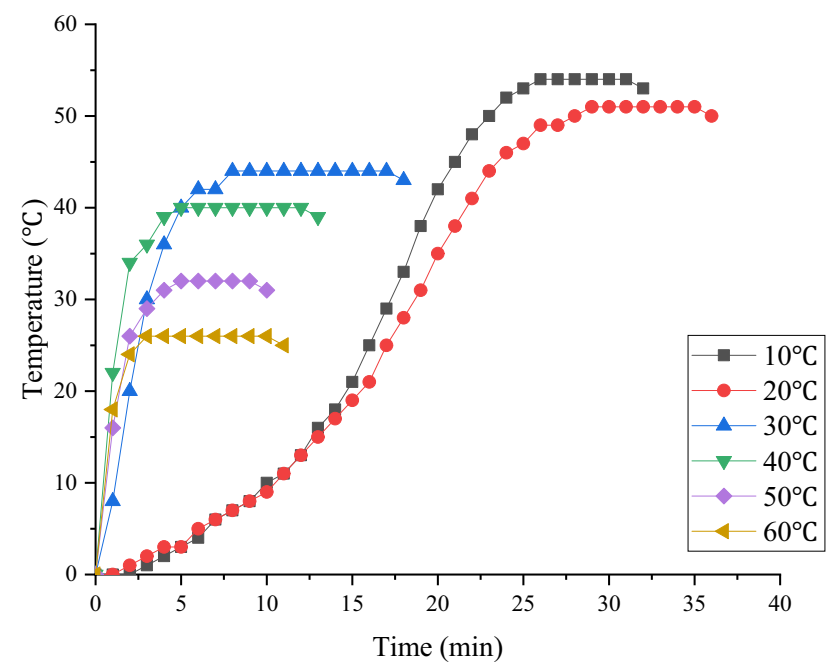

Fig. 14 Effect of ambient temperature on heating performance

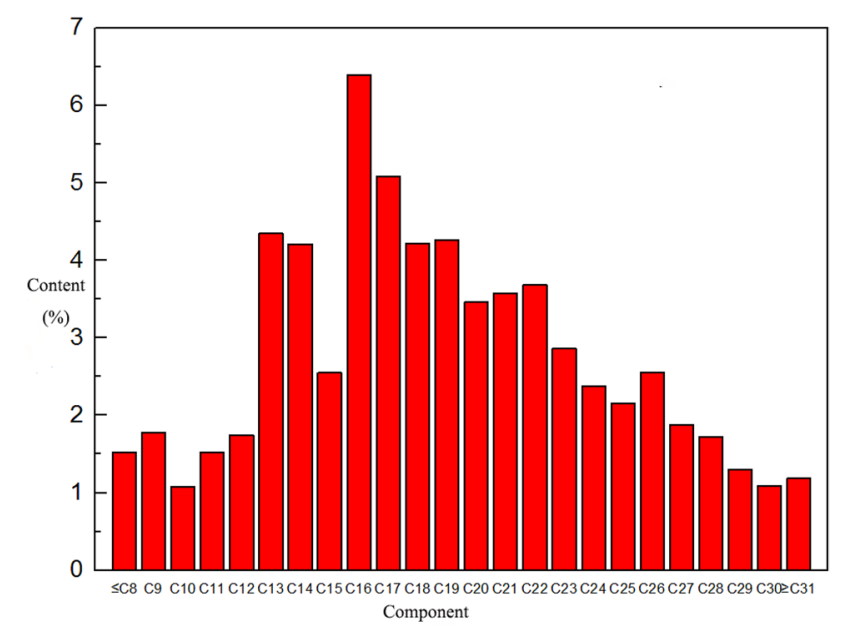

Fig. 15 Oil phase chromatography results

displacement on an artificial core, and the selected in situ heat system was used to perform the damage removal experiment on the core. Based on scanning electron microscope photographs and macroscopic permeability changes, the system's removal of the cold damage was observed.

(1) At a room temperature of $20^{\circ} \mathrm{C}$, a gas chromatograph was used to detect the composition of crude oil; Fig. 15 shows the specific experimental setup. The wax melting point and wax precipitation point experiments of the crude oil were conducted by a rheometer, and the values were determined by curve fitting. The freezing point experiment used the pour point method for detection. Table 4 shows the experimental data of the wax
Table 4 Wax melting point, wax precipitation point, and freezing point of the formation crude oil

\begin{tabular}{llll}
\hline Sample & $\begin{array}{l}\text { Wax melting } \\
\text { point }\left({ }^{\circ} \mathrm{C}\right)\end{array}$ & $\begin{array}{l}\text { Wax precipita- } \\
\text { tion point }\left({ }^{\circ} \mathrm{C}\right)\end{array}$ & $\begin{array}{l}\text { Freezing point } \\
\left({ }^{\circ} \mathrm{C}\right)\end{array}$ \\
\hline $\begin{array}{c}\text { Formation } \\
\text { crude oil }\end{array}$ & 50 & 40 & 14 \\
\hline
\end{tabular}

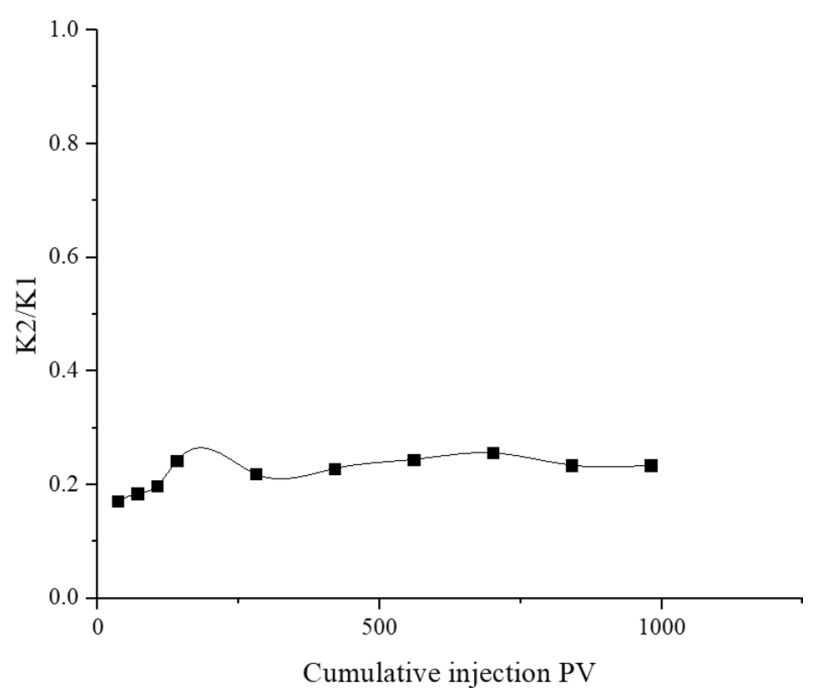

Fig. 16 Experimental results of crude oil cold damage

melting point, wax precipitation point, and freezing point.

(2) At a room temperature of $20{ }^{\circ} \mathrm{C}, 1 \mathrm{~L}$ of standard saline $\left(\mathrm{NaCl}: \mathrm{CaCl}_{2}: \mathrm{MgCl}_{2} \cdot 6 \mathrm{H}_{2} \mathrm{O}=7: 0.6: 0.4\right)$ was prepared. A core damage device was used to conduct a core displacement damage experiment. In the experiment, the flow rate of the flowing medium was lower than the critical flow rate, and the flow rate and pressure difference were stabilized; then, the pressure difference and flow rate were recorded. Standard salt water was used to measure the core permeability $\left(\mathrm{K}_{1}\right)$ before damage. The formation crude oil was displaced, followed by the standard salt water. The permeability $\left(\mathrm{K}_{2}\right)$ after damage was measured, and the core damage curve was drawn. Figure 16 shows the experimental results.

(3) At a room temperature of $20{ }^{\circ} \mathrm{C}, 1 \mathrm{~L}$ of standard saline and $1 \mathrm{~L}$ of the in situ heat system $(1.6 \mathrm{~mol} / \mathrm{L}$ ammonium chloride, $1.0 \mathrm{~mol} / \mathrm{L}$ sodium nitrite, and $0.8 \% \mathrm{HCl}$ ) were prepared. The core damage device was used to conduct a core displacement damage experiment. In the experiment, the flow rate of the flowing medium was lower than the critical flow rate, and the flow rate and pressure difference were 


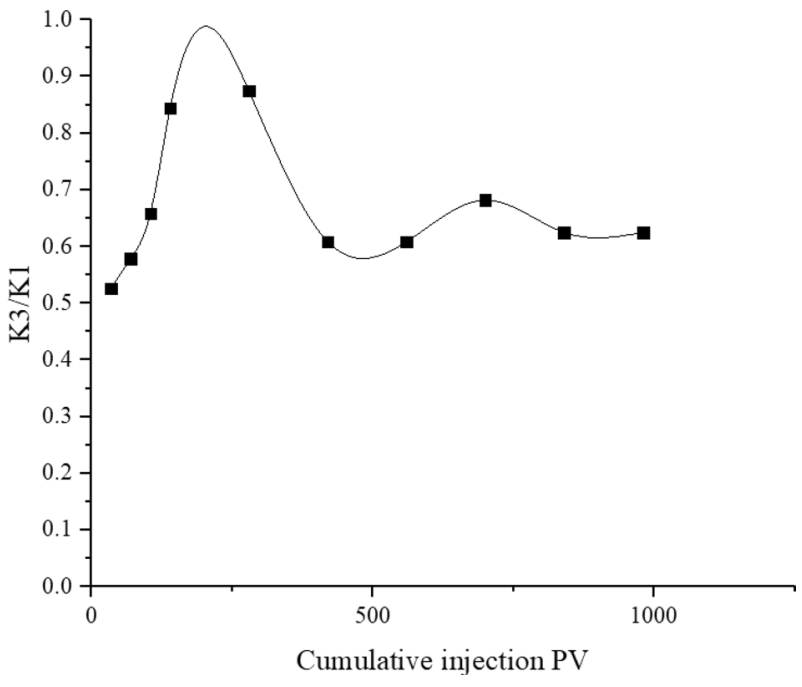

Fig. 17 Experimental results of crude oil cold damage relief stabilized; then, the pressure difference and flow rate were recorded. Standard salt water was used to measure the core permeability $\left(\mathrm{K}_{1}\right)$ before damage. The formation crude oil was displaced, followed by the standard brine. The standard brine was finally displaced; the permeability $\left(\mathrm{K}_{2}\right)$ after the cold damage was measured, and the core damage curve was drawn. The heat system was displaced after the cold damage to relieve the damage caused by the crude oil. Figure 17 shows the experimental results.

(4) At a room temperature of $20{ }^{\circ} \mathrm{C}$, three sets of cores that one were not damaged, one were damaged by crude oil, and one damaged by crude oil were removed to prepare SEM samples. The pores of the three cores were observed by scanning electron microscopy, and Figs. 18, 19 and 20 show the experimental results.
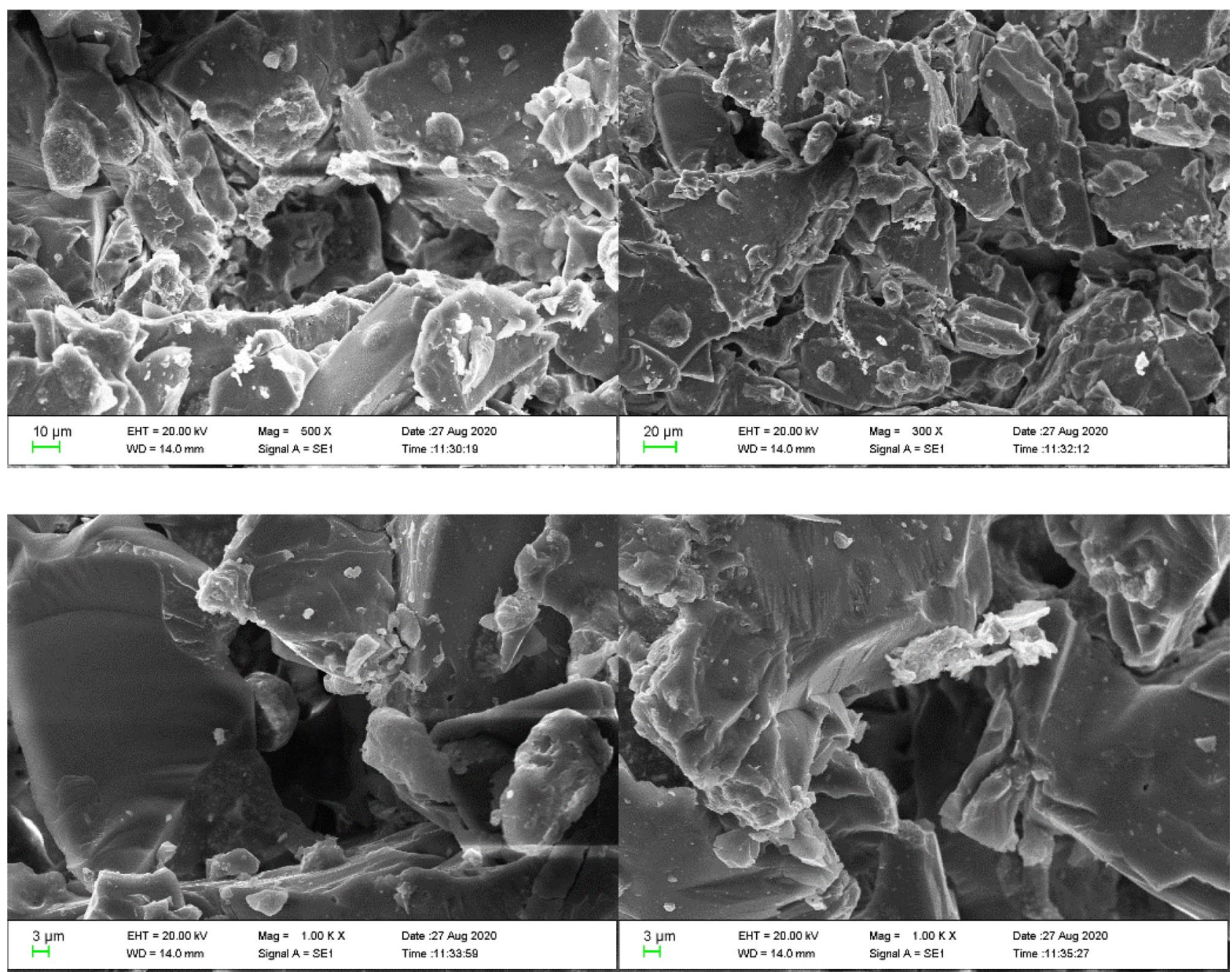

Fig. 18 Undamaged core pore structure (scanning electron microscope images)

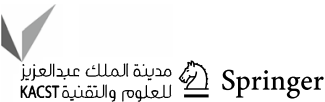



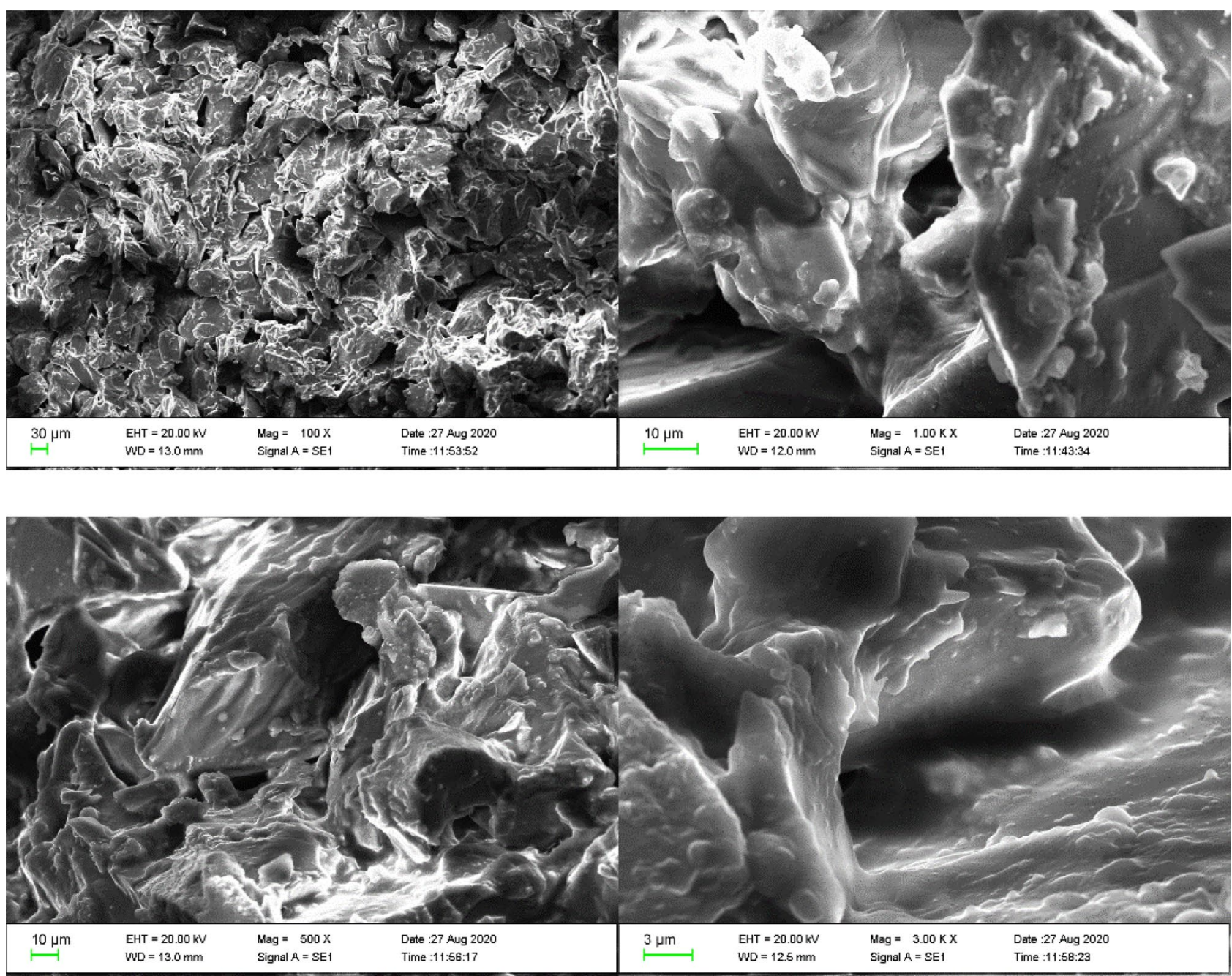

Fig. 19 Damaged core pore (scanning electron microscope images)

\section{Experimental results and discussion}

\section{Performance evaluation of in situ heat systems and optimization of heat-generating agent}

\section{Peak temperature}

The peak temperature was the highest temperature the in situ heat systems could reach and directly determined the systems' heating performance. Laboratory experiments were performed on the peak temperature of different heat-generating systems, and different heat-generating agents were selected. In Tables 1 and 2, in terms of heating performance, both the peak temperature and the peak temperature arrival time were the best for system B. In the experiments, it was found that the system of urea and sodium nitrite produced a large amount of brown gas, i.e., the by-product $\mathrm{NO}_{\mathrm{X}}$.

\section{Gas production}

The heat energy and gas production of the in situ heat systems were the main indicators used to evaluate the performance, as they directly affected the performance of the entire working fluid system. Different types of heatgenerating agents directly led to different heat energy and gas production performance in the systems.

Figure 21 shows that the greater the concentration of the heat-generating agent, the greater the rate of the heatgenerating reaction. The $2.5 \mathrm{~mol} / \mathrm{L}$ heat-generating agent concentration had the highest reaction peak pressure and the fastest heat generation rate. The higher the concentration of the heat-generating agent, the faster the peak pressure of the heat-generating reaction was reached. In Fig. 22, the peak pressure and reaction rate of the two<smiles>C1C2CC12</smiles> 

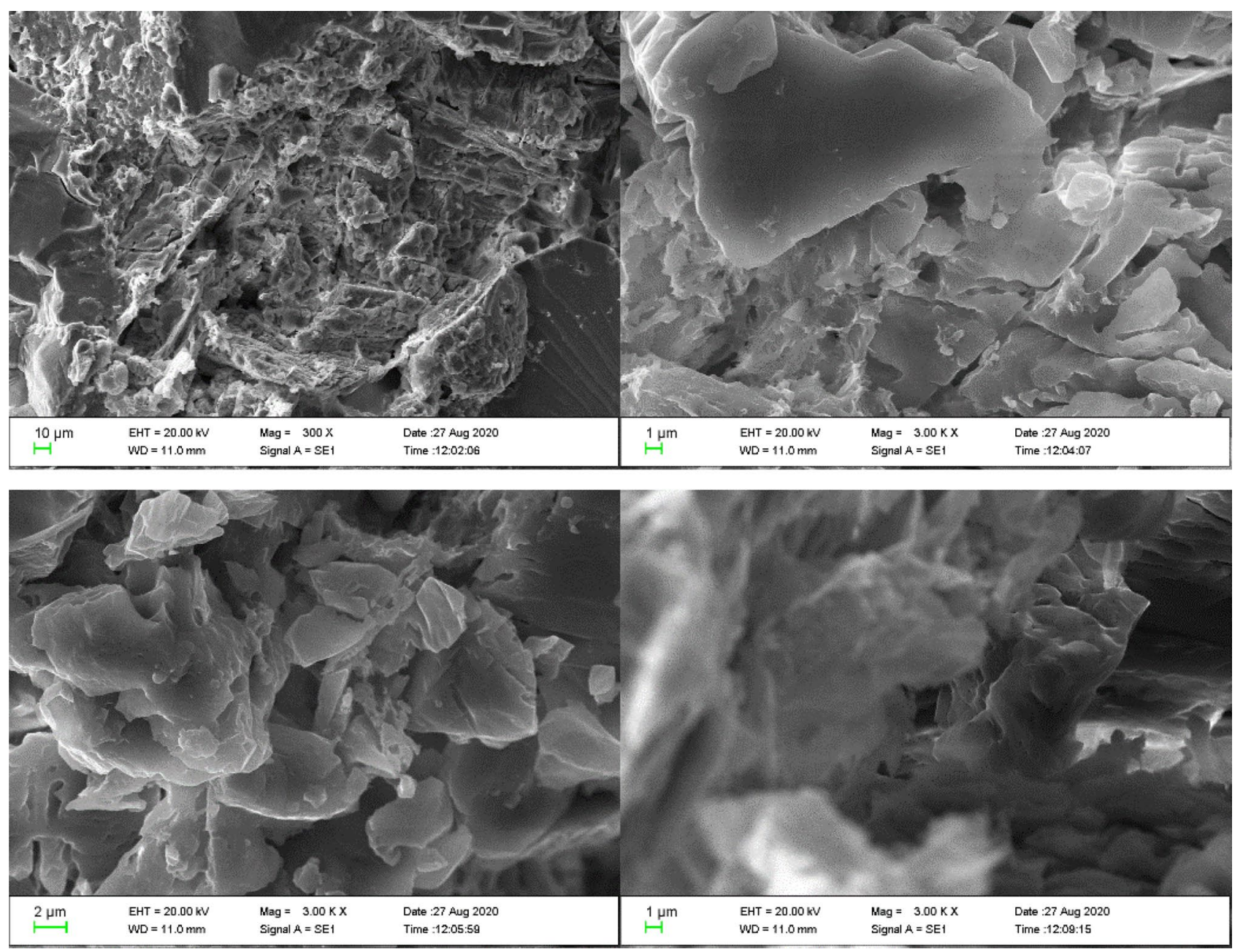

Fig. 20 Core pore after damage removed (scanning electron microscope images)

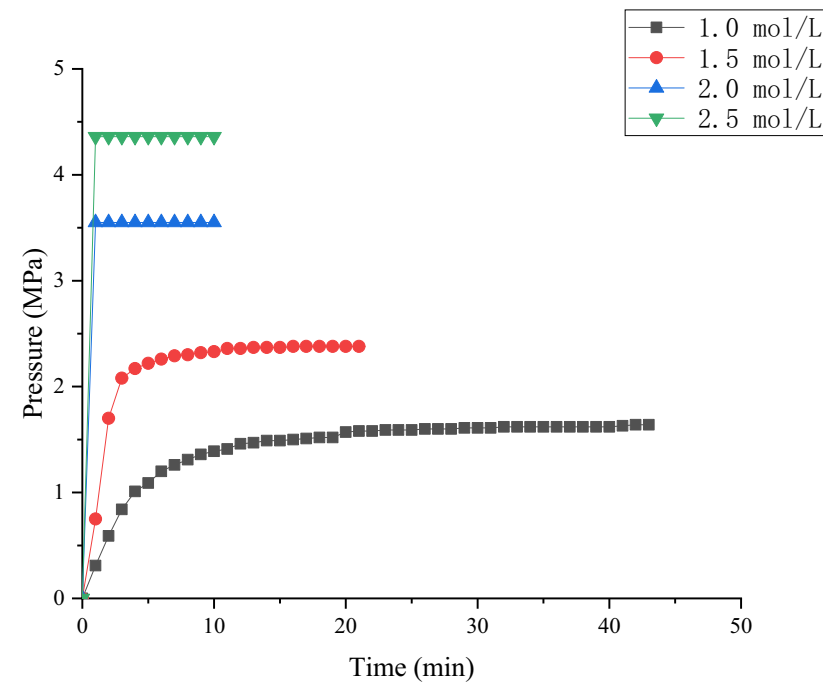

Fig. 21 Pressure-boosting performance of different concentrations of heat-generating agents

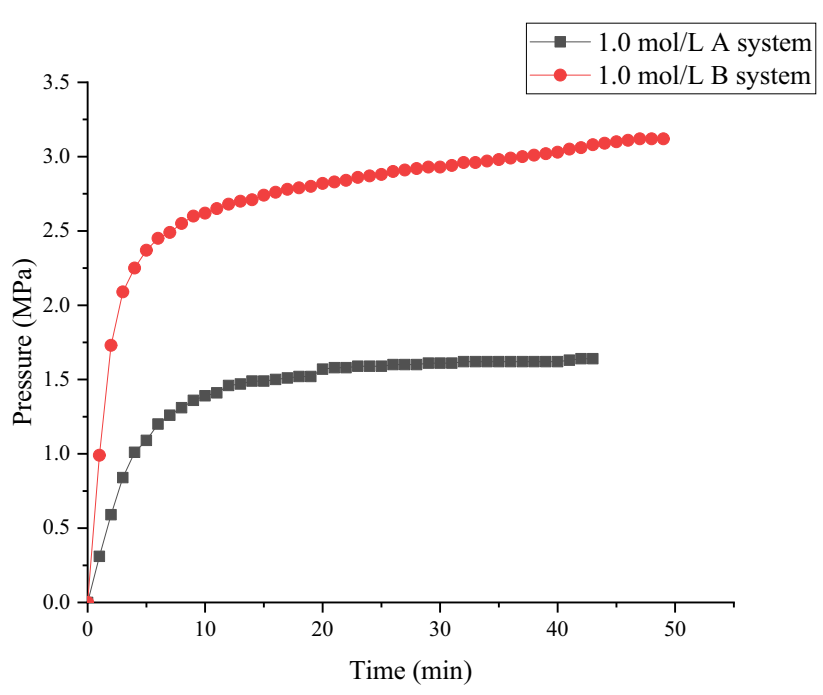

Fig. 22 Pressure-boosting performance of different in situ heat systems

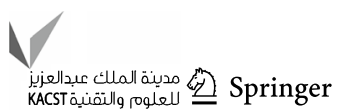


Table 5 Peak temperature and arrival time of the system with different catalyst concentrations

\begin{tabular}{|c|c|c|c|c|c|c|}
\hline \multirow{2}{*}{$\begin{array}{l}\text { Catalyst concen- } \\
\text { tration }(\%)\end{array}$} & \multicolumn{2}{|l|}{$\mathrm{HCl}$} & \multicolumn{2}{|l|}{ Sulfamic acid } & \multicolumn{2}{|l|}{ Citric acid } \\
\hline & $\begin{array}{l}\text { Peak tempera- } \\
\text { ture }\left({ }^{\circ} \mathrm{C}\right)\end{array}$ & $\begin{array}{l}\text { Arrival time } \\
\text { (min) }\end{array}$ & $\begin{array}{l}\text { Peak tempera- } \\
\text { ture }\left({ }^{\circ} \mathrm{C}\right)\end{array}$ & $\begin{array}{l}\text { Arrival time } \\
\text { (min) }\end{array}$ & $\begin{array}{l}\text { Peak tempera- } \\
\text { ture }\left({ }^{\circ} \mathrm{C}\right)\end{array}$ & $\begin{array}{l}\text { Arrival } \\
\text { time } \\
\text { (min) }\end{array}$ \\
\hline 1 & 50 & 44 & 53 & 21 & 53 & 34 \\
\hline 2 & 44 & 19 & 59 & 10 & 53 & 23 \\
\hline 3 & 35 & 16 & 42 & 3 & 50 & 17 \\
\hline 4 & 20 & 16 & 40 & 2 & 49 & 17 \\
\hline
\end{tabular}

systems are compared. It was found that the peak pressure of system B was greater than the peak pressure of system A. Thus, system B had a better pressure-boosting performance and larger gas production.

\section{Causticity}

The main indicators for evaluating the performance of the in situ heat systems, except for heat energy and gas production, included the evaluation of the corrosion status of the downhole oil string.

In Table 3, at the same molar concentration, the corrosion rate of system $\mathrm{B}$ was greater than that of system A; the bumping phenomenon was obvious, and the corrosion was strong.

Through the analysis of the three performance evaluation experiment results of the peak temperature, gas production, and causticity, the heat generation, gas production, and corrosivity of system A were lower than those of system B. From the perspective of economic costs and on-site construction safety, the heat-generating agent content of the urea and sodium nitrite system was approximately twice that of the ammonium chloride and sodium nitrite system;

Table 6 Peak temperature and arrival time of the system with different 1 \# catalyst concentrations

\begin{tabular}{lll}
\hline $\mathrm{HCl}$ concentration $(\%)$ & Peak temperature $\left({ }^{\circ} \mathrm{C}\right)$ & $\begin{array}{l}\text { Arrival } \\
\text { time } \\
(\mathrm{min})\end{array}$ \\
\hline 0.4 & 49 & 50 \\
0.6 & 50 & 48 \\
0.7 & 50 & 41 \\
0.8 & 51 & 43 \\
0.9 & 51 & 36 \\
1.0 & 51 & 43 \\
1.1 & 51 & 29 \\
1.2 & 51 & 34 \\
1.4 & 49 & 30 \\
1.6 & 49 & 22 \\
1.8 & 47 & 21 \\
2.0 & 44 & 17 \\
\hline
\end{tabular}

the reaction was relatively violent, and the potential safety hazard was greater. The heat generation and gas production capacity of the latter system was more in line with engineering applications and produced lower corrosion; therefore, it would be safer and more practical to choose this system.

\section{Study on the influence factors of heat generation of the in situ heat system of sodium nitrite and ammonium chloride}

\section{Effect of the type of heat-generating agent on the heat generation rate}

The experimental data in Figs. 4 and 5 are the changes in absolute temperature with time. As shown, the greater the concentration of the heat-generating agent, the higher the peak temperature and the faster the rate of heat generation. The peak temperature of the concentration of $3 \mathrm{~mol} / \mathrm{L}$ was the largest, and the rate of heat generation was the fastest.

Figure 4 compares the peak temperature of the different concentrations of heat-generating agents in each group. The peak temperature and heat generation rate of system $\mathrm{B}$ were greater than those of system A. The difference in peak temperature of the adjacent experimental groups of system $B$ was more average, and the temperature rise was more stable and better than that of system A. Thus, the heat generation efficiency of system B was better. However, the heat and gas production capacity of the heat-generating system of ammonium chloride and sodium nitrite was more suitable for engineering applications, and the degree of corrosion

Table 7 Peak temperature and arrival time of different temperature gradients

\begin{tabular}{lll}
\hline Ambient temperature $\left({ }^{\circ} \mathrm{C}\right)$ & Peak temperature $\left({ }^{\circ} \mathrm{C}\right)$ & $\begin{array}{l}\text { Arrival } \\
\text { time } \\
(\mathrm{min})\end{array}$ \\
\hline 10 & 54 & 25 \\
20 & 51 & 29 \\
30 & 44 & 8 \\
40 & 40 & 5 \\
50 & 32 & 5 \\
60 & 26 & 3
\end{tabular}


Table 8 Peak temperature of different heat-generating agent concentrations

\begin{tabular}{llll}
\hline Number & $\begin{array}{l}\text { Heat-generating agent concen- } \\
\text { tration }(\mathrm{mol} / \mathrm{L})\end{array}$ & $\begin{array}{l}\text { Peak temperature of } 1.0 \mathrm{~mol} / \mathrm{L} \\
\mathrm{NaNO}_{2}\left({ }^{\circ} \mathrm{C}\right)\end{array}$ & $\begin{array}{l}\text { Peak temperature of } \\
1.0 \mathrm{~mol} / \mathrm{L} \mathrm{NH}_{4} \mathrm{Cl}\left({ }^{\circ} \mathrm{C}\right)\end{array}$ \\
\hline 1 & 1.0 & 36 & 36 \\
2 & 1.1 & 42 & 36 \\
3 & 1.2 & 42 & 40 \\
4 & 1.3 & 42 & 49 \\
5 & 1.4 & 47 & 51 \\
6 & 1.5 & 48 & 53 \\
7 & 1.6 & 48 & 53 \\
8 & 1.7 & 52 & 55 \\
9 & 1.8 & 52 & 56 \\
10 & 1.9 & 54 & 61 \\
11 & 2.0 & 54 & 62 \\
\hline
\end{tabular}

was lower; hence, it would be safer and more practical to choose this system (Tables 5, 6, 7).

\section{Effect of the concentration of heat-generating agent on the heat generation rate}

Figures 7 and 8 clearly show that the concentration of the heat-generating agent was directly proportional to the reaction degree and reaction rate of the system. As the concentration of a certain heat-generating agent continued to increase, the reaction degree increased, the reaction rate increased, and the peak temperature rose.

Table 8 provides the peak temperature of each heat-generating agent concentration in this experiment. In experiment (1), the temperature changes in the three groups of $1-1.1,1.3-1.4$, and $1.6-1.7 \mathrm{~mol} / \mathrm{L}$ were obvious. The difference between the peak temperature of adjacent concentrations was defined as $\mathrm{T}_{\mathrm{i}}-\mathrm{T}_{\mathrm{i}-1}(i=2,3, \ldots, 11$; $\mathrm{i}$ is the group name), and the average value of the difference was $1.8^{\circ} \mathrm{C}$. A higher concentration of $\mathrm{NH}_{4} \mathrm{Cl}$ generated heat faster and reached the heat peak faster. In experiment (2), the temperature changes in the three groups of 1.1-1.2, 1.2-1.3, and $1.8-1.9 \mathrm{~mol} / \mathrm{L}$ were obvious as well. The difference between the peak temperature of adjacent concentrations was defined as $T_{i}-T_{i-1}(i=2,3, \ldots, 11)$, and the average value of the difference was $2.6{ }^{\circ} \mathrm{C}$. A higher concentration of $\mathrm{NaNO}_{2}$ generated heat faster and reached the heat peak faster. In the experiment, it was found that as the concentration of sodium nitrite increased, the system produced a large amount of brown gas, i.e., by-product $\mathrm{NO}_{\mathrm{x}}$. As the concentration of ammonium chloride increased, the amount of brown gas produced decreased.

Upon comparing the heating performance of $\mathrm{NaNO}_{2}$ and $\mathrm{NH}_{4} \mathrm{Cl}$, the magnitude of their influence on the heatgenerating reaction was analyzed. According to the difference in peak temperature, when the concentration ratio of the heat-generating agent approached one, changing the concentration of $\mathrm{NH}_{4} \mathrm{Cl}$ could significantly promote the system reaction. As the concentration of the heat-generating agent increased, the promoting effect of $\mathrm{NaNO}_{2}$ became more obvious, and the rate of temperature increase continuously rose. Thus, by increasing the concentration of a certain heat-generating agent, the heat-generating reaction was promoted, the reaction rate was increased, and the temperature rise performance was improved. The experiment determined that the optimal concentration of the heat-generating agent was $1.6 \mathrm{~mol} / \mathrm{L} \mathrm{NH}_{4} \mathrm{Cl}$ and $1.0 \mathrm{~mol} / \mathrm{L} \mathrm{NaNO}_{2}$.

\section{Effect of the catalyst type on the heat generation rate}

Here, $\mathrm{HCl}$, sulfamic acid, and $\mathrm{CA}$ were chosen as the catalysts of $\mathrm{NaNO}_{2}$ and $\mathrm{NH}_{4} \mathrm{Cl}$. At the catalyst concentrations of $1 \%$ and $2 \%$, the temperature rise rate of sulfamic acid was the fastest and the peak temperature the largest. The peak temperature of $\mathrm{HCl}$ was lower than that of CA. At the catalyst concentrations of $3 \%$ and $4 \%$, the peak temperature of CA was the largest, and the peak temperature of $\mathrm{HCl}$ was the lowest. The heating rate of sulfamic acid was the fastest, that of $\mathrm{HCl}$ was the second fastest, and that of $\mathrm{CA}$ was the slowest. In the experiment, it was found that as the concentration of the catalyst increased, the system produced a large amount of brown gas, i.e., by-product $\mathrm{NO}_{\mathrm{x}}$. Hence, a catalyst with a low $\mathrm{H}^{+}$concentration and high heat release should be selected.

A comprehensive experimental data analysis showed that at the $1 \%$ and $2 \%$ concentrations, the temperature rise performance of sulfamic acid was the best and reached the peak temperature faster. However, among the $3 \%$ and $4 \%$ concentrations, CA had better catalytic efficiency and reached the peak temperature faster. The temperature rise performance of the same catalyst in different concentration ranges also differed. The temperature rise performance of the heat-generating reaction did not have a positive correlation with the 
reaction rate, and the optimal catalyst concentration existed. The optimal catalyst concentration of the CA was relatively high, and a large amount of the harmful by-product $\mathrm{NO}_{\mathrm{X}}$ was produced.

As sulfamic acid has strong oxidizing properties, it can oxidize $\mathrm{NaNO}_{2}$ and affect the progress of the heat-generating reaction; thus, its concentration effect will not be discussed here. $^{2}$

\section{Effect of the catalyst concentration on the heat generation rate}

According to the heat-generating reaction results of the different catalyst concentrations, it was observed that there was an optimal concentration of catalyst in the system. As the concentration of $\mathrm{HCl}$ increased, the peak temperature of the system rose and then decreased; the overall temperature increase rate of the system showed an upward trend, and the optimal catalyst concentration existed in the system. The $0.4 \% \mathrm{HCl}$ system had a poor heating performance, a low heating rate, and a peak temperature of $49^{\circ} \mathrm{C}$. As the $\mathrm{HCl}$ catalyst concentration increased, the system heating performance was enhanced, the heating rate was accelerated, and the peak temperature continued to rise. The maximum peak temperature was reached at $0.8 \% \mathrm{HCl}$. When the concentration of $\mathrm{HCl}$ was greater than $1.2 \%$, the system heating rate gradually increased, but the peak temperature continued to decrease, as did the heat generation efficiency. Thus, under this concentration of heat-generating agent, the optimal catalyst concentration should be screened within a range of $0.8 \%-1.2 \%$ according to the actual heating rate.

\section{Effect of the ambient temperature on the heat generation rate}

According to the heating curve prepared from the experimental data, the reaction between $\mathrm{NaNO}_{2}$ and $\mathrm{NH}_{4} \mathrm{Cl}$ was in accordance with the general rule of exothermic reactions. As the ambient temperature increased, the reaction degree decreased, the peak temperature decreased, and the rate of temperature increase greatly increased.

The temperature rise rate of the system was directly proportional to the ambient temperature. The higher the ambient temperature, the faster the temperature rise rate. Therefore, the peak temperature of the system was higher at a room temperature of $20^{\circ} \mathrm{C}$ and below, but at a higher temperature, the temperature increase rate of the system greatly increased.

\footnotetext{
${ }^{2}$ Sulfamic acid reacts with sodium nitrite, and the reaction releases a lot of heat. This would have affected the experimental determination of the effect of the $\mathrm{H}^{+}$concentration on the heat generation of the sodium nitrite and ammonium chloride system. The reaction equation is $\mathrm{NH}_{2}-\mathrm{SO}_{3} \mathrm{H}+\mathrm{HNO}_{2}=\mathrm{N}_{2}+\mathrm{H}_{2} \mathrm{O}+\mathrm{H}_{2} \mathrm{SO}_{4}$.

\section{Experiment of cold damage removal by in situ heat system}

(1) Analysis of physical properties of waxy high-pour-point oil in a reservoir

According to the gas chromatograph results, the main peak carbon was $\mathrm{C} 16$, the mass fraction with a carbon content of less than 16 was $18.7608 \%$, and the mass fraction with a carbon content of more than 16 was $81.2382 \%$. The wax precipitation point of the formation crude oil was $40{ }^{\circ} \mathrm{C}$, and the wax melting point was $50{ }^{\circ} \mathrm{C}$. To relieve cold damage from a reservoir, the reservoir temperature must be higher than $50{ }^{\circ} \mathrm{C}$. Moreover, based on the wax melting point and wax precipitation point, once the formation cold damage occurs, a higher temperature is required to remove it.

(2) Experimental results of crude oil cold damage

(3) Experimental results of crude oil cold damage relief

(4) SEM experiment results

According to the results of the crude oil cold damage experiment, the core damage rate finally stabilized at $77 \%$. Crude oil cold damage has a great impact on the porosity and permeability of a reservoir, and an in situ heat system should avoid its occurrence. According to the results of the crude oil cold damage removal experiment, the core damage rate was finally stabilized at $37.5 \%$. Displacing the in situ heat system removed the plugging of the crude oil cold damage in the core, and the core's porosity and permeability were significantly improved. Upon comparing the three sets of scanning electron microscopy core photographs, the undamaged cores had a good pore structure, the cores damaged by crude oil were blocked, and the cores whose cold damage was removed had an improved pore structure although some pore blockages still existed.

\section{Reaction Kinetic Mechanism}

A reaction kinetic equation reflects the quantitative relationship between the reaction rate of a chemical reaction and each reaction parameter. In practical applications, the reaction rate of the in situ heat system injected into a formation could be predicted and controlled through the kinetic equation of the system's reaction according to known formation conditions. The reaction kinetic equation of sodium nitrite and ammonium chloride proposed by Nguyen et al. can be expressed as:

$\frac{\mathrm{d} c}{\mathrm{~d} t}=-A e^{-\frac{\Delta E}{R T}} c\left(\mathrm{NaNO}_{2}\right)^{n_{1}} c\left(\mathrm{NH}_{4} \mathrm{Cl}\right)^{n_{2}} c\left(\mathrm{H}^{+}\right)^{n_{3}}$. 
where $A, n_{1}, n_{2}, n_{3}, \Delta E$ are the parameters to be determined; $\mathrm{d} c / \mathrm{d} t$-instantaneous reaction rate, $\mathrm{mol} /(\mathrm{L} \mathrm{s}) ; A-$ pre-referred factor; $c\left(\mathrm{H}^{+}\right)$-hydrogen ion concentration, $\mathrm{mol} / \mathrm{L} ; n_{3}$-hydrogen ion reaction order; $c\left(\mathrm{NaNO}_{2}\right)$ - the concentration of $\mathrm{NaNO}_{2}, \mathrm{~mol} / \mathrm{L} ; n_{1}$-the reaction order of $\mathrm{NaNO}_{2} ; c\left(\mathrm{NH}_{4} \mathrm{Cl}\right)-\mathrm{NH}_{4} \mathrm{Cl}$ concentration, $\mathrm{mol} / \mathrm{L} ; n_{2}-$ $\mathrm{NH}_{4} \mathrm{Cl}$ reaction order; $\Delta E$ - activation energy, $\mathrm{KJ} / \mathrm{mol} ; R$ gas constant. $8.314 \mathrm{~J} /(\mathrm{mol} \cdot \mathrm{K})$.

Taking the reaction concentration of sodium nitrite and ammonium chloride as 1:1, the formula can be simplified as:

$\frac{\mathrm{d} c}{\mathrm{~d} t}=-A e^{-\frac{\Delta E}{R T}} c_{0}^{n} c\left(\mathrm{H}^{+}\right)^{n_{3}}$.

In the formula, $c_{0}$ is the initial concentration of reactant, $\mathrm{mol} / \mathrm{L} ; n=n_{1}+n_{2}$.

Shift and integrate the formula:

$t=\frac{v^{n-1}-1}{n-1} A^{-1} e^{\frac{\Delta E}{R T}} c_{0}^{1-n} c\left(\mathrm{H}^{+}\right)^{-n_{3}}$.

In the formula, $\nu$ is the ratio of the initial concentration of the reactant to the remaining concentration.

Upon combining the experimental results from this paper and using the system heat change value instead of the system reactant concentration change, the following formula was obtained:

$\left\{\begin{array}{l}t=\frac{m^{n-1}-1}{n-1} A^{-1} e^{\frac{\Delta E}{R T}} c_{0}^{1-n} c\left(\mathrm{H}^{+}\right)^{-n_{3}} . \\ m=\frac{\Delta H}{\Delta H-\Delta Q}\end{array}\right.$.

In the formula, $m$ is the ratio of the difference between the theoretical heat generation value and the real-time heat generation value; $\Delta H$ is the theoretical calorific value, $\mathrm{KJ}$; $\Delta Q$ is the real-time heating value, $\mathrm{KJ}$.

Take the logarithmic transformation to get:

$\ln t=\ln \left(\frac{m^{n-1}-1}{n-1}\right)-\ln A-n_{3} \ln c\left(\mathrm{H}^{+}\right)+(1-n) \ln c_{0}+\frac{\Delta E}{R T}$

$\lg t=\lg \left(\frac{m^{n-1}-1}{n-1}\right)-\lg A-n_{3} \lg c\left(\mathrm{H}^{+}\right)$

$+(1-n) \lg c_{0}+\frac{\Delta E}{2.303 R T}$.

\section{Determination of activation energy}

When initial concentration $\mathrm{c}_{0}$, hydrogen ion concentration $c\left(\mathrm{H}^{+}\right)$, and $\mathrm{m}$ were the same, $\ln t$ had a linear relationship with $1 / T$ and $\Delta E / R$ was the linear slope. In the experiment, $\mathrm{m}$ was reflected by the heat generation. When the same temperature difference occurred under different temperature conditions, $\mathrm{m}$ was the same. When $\mathrm{m}$ was the same, $\ln t$ and $1 / T$ images

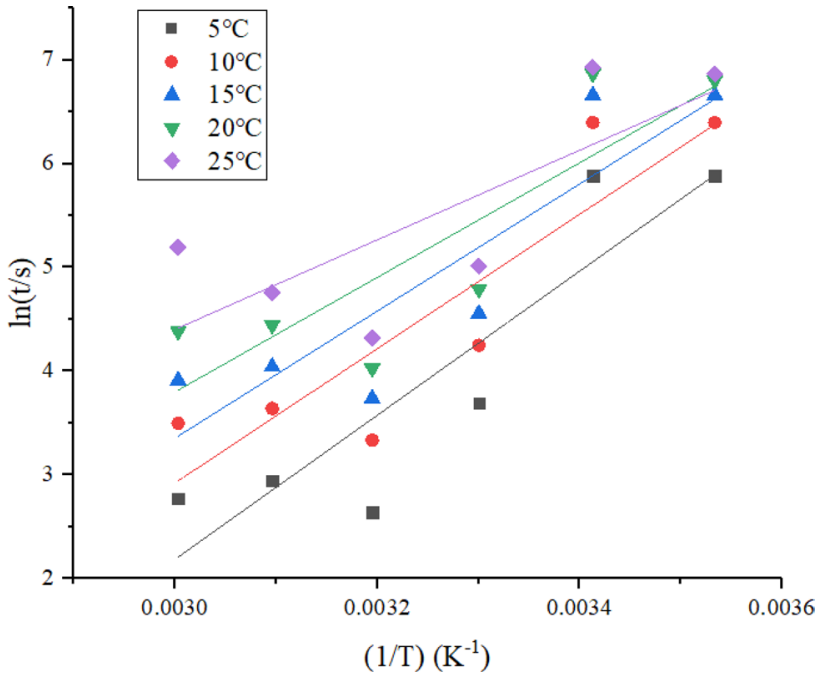

Fig. 23 Linear relationship between lnt and 1/T

according to the experimental data were created, and linear fitting was performed. The average value of the slope at different temperature differences was taken, and the slope equal to $\Delta E / R$ was used to calculate the reaction activation energy, $\Delta E=48.879 \mathrm{~kJ} / \mathrm{mol}$ (Fig. 23).

\section{Determination of reaction order $n_{1} n_{3}$}

When initial concentration $c_{0}$, temperature $T$, and $m$ were the same, the relationship between $\lg t$ and $-\lg c\left(\mathrm{H}^{+}\right)$was linear, and $\mathrm{n}_{3}$ was the linear slope. In the experiment, $\mathrm{m}$ was reflected by heat generation. When $\mathrm{m}$ was the same, $\lg t$ and $-\lg c\left(\mathrm{H}^{+}\right)$ images were created according to the experimental data, and linear fitting was performed. The average of the slopes at different temperature differences was taken, and the slope equal to $n_{3}$ was used to calculate the acid reaction order, $n_{3}=0.6455$ (Fig. 24).

When temperature $T$, hydrogen ion concentration $c\left(\mathrm{H}^{+}\right)$, and $\mathrm{m}$ were the same, the relationship between $\lg t$ and $\lg c_{0}$ was linear, and $n$ was the slope of the line. In the experiment, $m$ was reflected by heat generation. When $m$ was the same, the images of $\lg t$ and $\lg c_{0}$ were created based on the experimental data, and linear fitting was performed. The average of the slopes at different temperature differences was determined, and the slope equal to $\mathrm{n}$ was used to calculate the acid reaction order, $n=2.4678$ (Fig. 25).

\section{Determination of pre-reference factors}

Combined with the intercept data of the fitted straight line, the activation energy $\Delta E=48.879 \mathrm{~kJ} / \mathrm{mol}$, and the reaction order $n, n_{3}$ : 


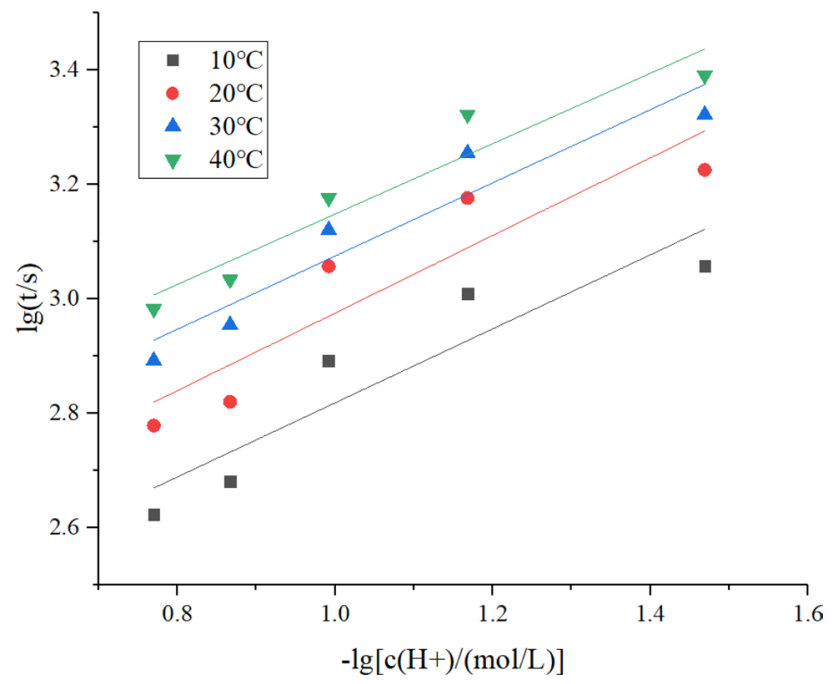

Fig. 24 Linear relationship between $\operatorname{lgt}$ and $-\lg \left[c\left(\mathrm{H}^{+}\right)\right]$

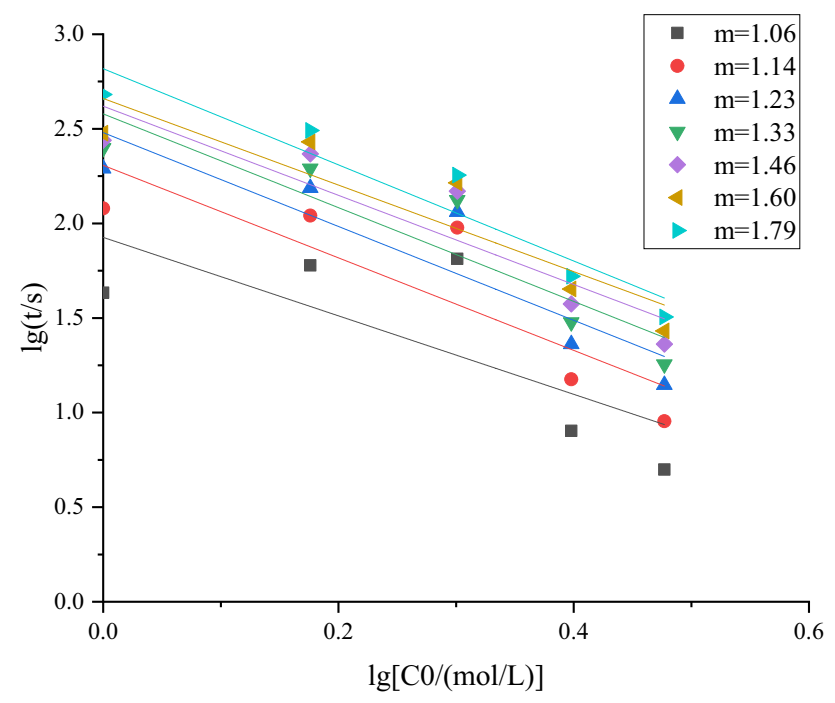

Fig. 25 Linear relationship between $\operatorname{lgt}$ and $\lg \left(c_{0}\right)$

$L=\ln \left(\frac{m^{n-1}-1}{n-1}\right)-\ln A-n_{3} \ln c\left(\mathrm{H}^{+}\right)+(1-n) \ln c_{0}$,

$L=\lg \left(\frac{m^{n-1}-1}{n-1}\right)-\lg A+(1-n) \lg c_{0}+\frac{\Delta E}{2.303 R T}$,

$L=\lg \left(\frac{m^{n-1}-1}{n-1}\right)-\lg A-n_{3} \lg c\left(\mathrm{H}^{+}\right)+\frac{\Delta E}{2.303 R T}$.

In the formula, $L$ is the intercept of the kinetic fitting curve.
Intercept $L$ of each fitted straight line was calculated, and the value of pre-exponential factor $A$ was obtained. The average value was calculated as $A=1.73 \times 10^{7}$.

\section{Determination of kinetic equation}

From the above data, the reaction kinetic equation of sodium nitrite and ammonium chloride under the experimental conditions was

$\frac{\mathrm{d} c}{\mathrm{~d} t}=-1.73 \times 10^{7} e^{-\frac{48.879}{R T}} c_{0}^{2.4678} c\left(\mathrm{H}^{+}\right)^{0.6455}$.

\section{Heat generation law of in situ heat system}

As the concentration of reactants increased in system A, the rate of heat generation increased rapidly; the peak temperature also increased, whereas the time to reach the peak value rapidly decreased. As the catalyst concentration increased, the faster the reaction rate, the faster the heating rate. The heat generation efficiency depended on the concentration of the heat-generating agent, and there were different optimal catalyst concentrations. However, the basic peak temperature range remained unchanged. The initial temperature of the reaction system had a greater influence on the rate of heat generation. As the initial temperature increased, the rate of heat generation increased, the peak temperature decreased, and the time to reach the peak value shortened significantly.

The in situ heat system with a temperature increase of $50{ }^{\circ} \mathrm{C}$ was optimized and combined with a fracturing fluid system for reservoir reconstruction. The system needed to reduce the $\mathrm{H}^{+}$concentration to meet the requirements of the fracturing fluid to effectively cross-link in a weakly acidic environment and completely break the gel. Moreover, to reduce the $\mathrm{NO}_{\mathrm{X}}$, the system had to reduce the concentration of reactant sodium nitrite and $\mathrm{H}^{+}$and have a high heat release. In the end, a system formula of $1.6 \mathrm{~mol} / \mathrm{L}$ ammonium chloride, $1.0 \mathrm{~mol} / \mathrm{L}$ sodium nitrite, and $0.8 \%$ hydrochloric acid was selected.

\section{Effect evaluation of in situ heat system}

Using the characteristics of the in situ heat system, an in situ heat fracturing fluid system was formed. The in situ heat fracturing fluid could increase the reservoir temperature by ensuring the formation of fractures in the reservoir and increasing the permeability, thus avoiding the cold damage issue and reducing the viscosity of the crude oil. The fluid generated a considerable amount of inert gas while generating heat, thus forming foam-like fracturing fluid. The system was able to reduce fluid loss, improve the sand-carrying performance, 


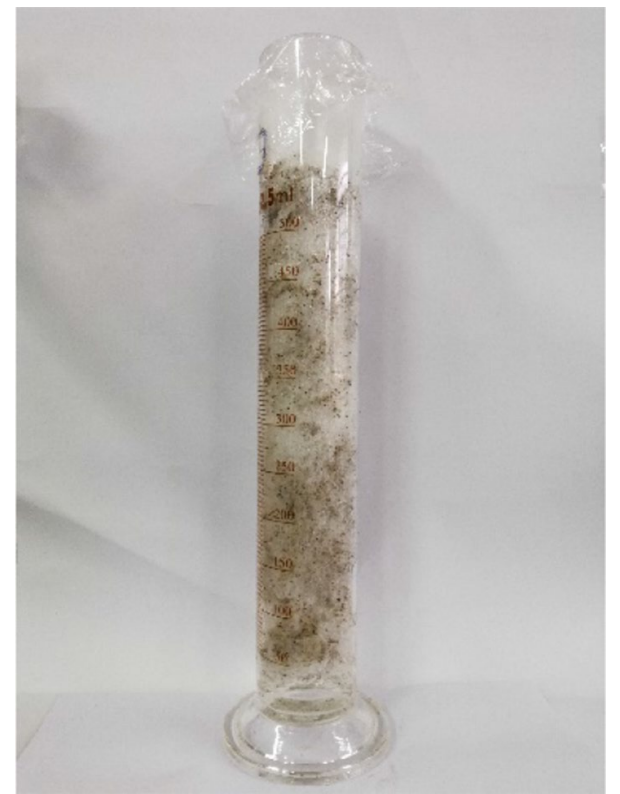

Fig. 26 Sand-carrying performance of in situ heat fracturing fluid system

improve the gel breaking and flowback performance, and effectively improve the fracture conductivity. Moreover, it was clean and environment-friendly (Fig. 26).

Compared with the conventional fracturing wells in the same block, the fracturing construction effect of five wells using the autogenous thermal fracturing fluid system was good. The average oil test output of conventional fracturing construction is $2.8 \mathrm{t} / \mathrm{d}$, and the average oil test output of the in situ heat fracturing fluid system was $13.2 \mathrm{t}$. After the official production, the average daily oil production per well was $2.15 \mathrm{t} / \mathrm{d}$, a 1.9 -fold increase compared with the previous $1.12 \mathrm{t} / \mathrm{d}$. Based on the relevant experimental conclusions and on-site construction applications, the in situ heat fracturing fluid system could effectively avoid the problem of cold damage to the working fluid, improve oil and gas production, and effectively cross-link and carry sand in an acidic environment. Moreover, the system's gel-breaking performance was good: The gel-breaking liquid was clear, did not contain residue, was clean and environment-friendly, and caused minimal damage.

\section{Conclusion}

In this paper, the performance of an in situ heat generation system was evaluated via laboratory experiments. Ammonium chloride and sodium nitrite were selected as the heat-generating agents, and 1\# catalyst was used as the catalyst. With the goals of reaching $50{ }^{\circ} \mathrm{C}$ and reducing the toxic and harmful by-product $\mathrm{NO}_{\mathrm{X}}$, a heat-generating formula with a low $\mathrm{H}^{+}$concentration was proposed. This formula achieved good results in the core flooding tests and on-site construction applications, and the following conclusions were drawn:

1. The optimum system was determined to be $1.6 \mathrm{~mol} / \mathrm{L}$ ammonium chloride, $1.0 \mathrm{~mol} / \mathrm{L}$ sodium nitrite, and $0.8 \%$ hydrochloric acid.

2. In the exothermic reaction of sodium nitrite and ammonium chloride, the higher the initial concentration of the exothermic agent and the lower the ambient temperature, the more heat was generated by the reaction. The kinetic equation was calculated based on the experimental results of the system heat production:

$$
\mathrm{d} c / \mathrm{d} t=1.73 \times 10^{7} e^{-\frac{48.879}{R T}} c_{0}^{2.4678} c\left(\mathrm{H}^{+}\right)^{0.6455} .
$$

3. In the core flooding experiment, the in situ heat system could relieve but not completely remove the cold damage.

4. The in situ heat system with a low $\mathrm{H}^{+}$concentration combined with the hydrophobic polymer fracturing fluid formed an in situ heat fracturing fluid system with effective cross-linking and complete gel-breaking properties and good on-site construction evaluation.

Overall, the in situ heat system could effectively be applied to reservoir wax removal and cold damage relief. Optimizing the system formula could solve the problems (e.g., the harmful by-product $\mathrm{NO}_{\mathrm{X}}$ ) that make adapting to the existing fracturing fluid system difficult. In the exploitation of unconventional oil and gas resources, the in-situ heat system could become more widely used due to its heat generation and gas production performance.

Acknowledgements This work was supported by the National Science and Technology Major Project and National Natural Science Foundation of China Petrochemical Joint Fund Project (U1762107).

Open Access This article is licensed under a Creative Commons Attribution 4.0 International License, which permits use, sharing, adaptation, distribution and reproduction in any medium or format, as long as you give appropriate credit to the original author(s) and the source, provide a link to the Creative Commons licence, and indicate if changes were made. The images or other third party material in this article are included in the article's Creative Commons licence, unless indicated otherwise in a credit line to the material. If material is not included in the article's Creative Commons licence and your intended use is not permitted by statutory regulation or exceeds the permitted use, you will need to obtain permission directly from the copyright holder. To view a copy of this licence, visit http://creativecommons.org/licenses/by/4.0/. 


\section{References}

Alade OS, Mahmoud M, Hassan A, Al-Shehri D, Al-Nakhli A, Bataweel M (2019) Evaluation of kinetics and energetics of thermochemical fluids for enhanced recovery of heavy oil and liquid condensate. Energy Fuels 33:5538-5543. https://doi.org/ 10.1021/acs.energyfuels.9b00681

Alade O, Mahmoud M, Hassan A, Murtaza M, Al-Shehri D, Al-Nakhli A, Bataweel M (2020) A novel method of removing emulsion blockage after drilling operations using thermochemical fluid. SPE Drill Compl. https://doi.org/10.2118/199315-PA

Al-Nakhli AR, Sukkar LA, Arukhe J, Mulhem A, Mohannad A, Ayub M, Arifin M (2016) In-situ steam generation a new technology application for heavy oil production. In: Paper presented at the SPE heavy oil conference and exhibition, Kuwait City, Kuwait, December 2016. https://doi.org/10.2118/184118-MS

Al-Taq AA, Al-Haji H, Saleem JA (2014) First Successful filtercake damage removal treatment utilizing in-situ nitrogen/heat generating system for relatively heavy oil wells. Soc Pet Eng. https://doi. org/10.2118/170832-MS

Al-Yaari M (2011) Paraffin wax deposition: mitigation \& removal techniques. In: Paper presented at the SPE Saudi Arabia section young professionals technical symposium, Dhahran, Saudi Arabia, March 2011. https://doi.org/10.2118/155412-MS

Ashton JP, Kirspel LJ, Nguyen HT, Credeur DJ (1989) In-situ heat system stimulates paraffinic-crude producers in Gulf of Mexico. Soc Pet Eng. https://doi.org/10.2118/15660-PA

Bayless JH (1997) Oil well stimulation with hydrogen peroxide. Soc Pet Eng. https://doi.org/10.2118/38348-MS

Collesi JB, Scott TA, McSpadden HW (1987) Surface equipment cleanup utilizing in-situ heat. Soc Pet Eng. https://doi.org/10. 2118/16215-MS

Davies DR, Richardson EA, Antheunis D (1981) Field application of in-situ nitrogen gas generation system. Soc Pet Eng. https://doi. org/10.2118/9653-MS

Demirbas A (2010) Methane hydrates as potential energy resource: part 2-methane production processes from gas hydrates. Energy Convers Manag 51(7):1562-1571. https://doi.org/10.1016/j.encon man.2010.02.014

Denney D (2008) Toward production from gas hydrates: status, technology, and potential. J Pet Technol 60(07):82-84. https://doi.org/ 10.2118/0708-0082-jpt

Evangelista E, Chagas CM, Melo JAF, Filho NB, Rocha JDH, do Carmo Marques LC (2009) Removal of a hydrate plug from a subsea Xmas-Tree located in ultradeepwaters with the aid of a heat-releasing treating Fluid. In: Paper presented at the offshore technology conference, Houston, Texas, May 2009. https://doi. org/10.4043/19730-MS

Feng JC, Yi W, Li XS (2018) Dissociation characteristics of watersaturated methane hydrate induced by huff and puff method. Appl Energy 211:1171-1178

Goenka SK, Singhal J, Kothiyal MD, Parasher A, Tiwari S (2014) 14). Near wellbore asphaltene and wax remediation using in-situ heat generation in both PCP and non-PCP wells: concept, operational challenges \& remedial solutions. Soc Pet Eng. https://doi.org/10. 2118/171497-MS

Hassan A, Mahmoud M, Al-Majed A, Al-Nakhli A, BaTaweel, M, Elktatany S (2019a) Permanent removal of condensate banking in tight gas reservoirs using thermochemicals. In: Paper presented at the SPE international conference on oilfield chemistry, Galveston, Texas, USA, April 2019. https://doi.org/10.2118/193609-MS

Hassan A, Mahmoud M, Al-Majed A, Alade O, Al-Nakhli A, BaTaweel M, Elktatany S (2019b) Development of a new chemical treatment for removing water blockage in tight reservoirs. In: Paper presented at the SPE Middle East oil and gas show and conference, Manama, Bahrain, March 2019. https://doi.org/10.2118/ 194879-MS

Hassan A, Mahmoud M, Al-Majed A, Al-Nakhli A (2020) Enhance the gas productivity for shale gas reservoirs using thermochemical treatment. In: Paper presented at the international petroleum technology conference, Dhahran, Kingdom of Saudi Arabia, January 2020. https://doi.org/10.2523/IPTC-19603-Abstract

Jamaluddin AKM, Hamelin M, Harke K, McCaskill H (1996) Field testing of the formation heat treatment process. Pet Soc Canada. https://doi.org/10.2118/96-88

Jamaluddin AKM, Bennion DB, Thomas FB, Ma TY (2000) Application of heat treatment to enhance permeability in tight gas reservoirs. Pet Soc Canada. https://doi.org/10.2118/00-11-01

Khalil CN, Franco ZDA (1990) Improving matrix acidizing with nitrogen and heat in-situ generation. Soc Pet Eng. https://doi. org/10.2118/21113-MS

Li S, Xu X, Zheng R, Chen Y, Jian H (2015) Experimental investigation on dissociation driving force of methane hydrate in porous media. Fuel 160:117-122. https://doi.org/10.1016/j.fuel.2015. 07.085

Li B, Liu SD, Liang YP, Liu H (2018) The use of electrical heating for the enhancement of gas recovery from methane hydrate in porous media. Appl Energy 227:694-702. https://doi.org/10. 1016/j.apenergy.2017.08.066

Matus ER, Mamora DD (2005) Top-injection and bottom-production (TINBOP) cyclic steam injection method enhances oil recovery. Soc Pet Eng. https://doi.org/10.2118/97850-MS

McSpadden HW, Tyler ML, Velasco TT (1986) In-situ heat and paraffin inhibitor combination prove cost effective in NPR \#3, Casper Wyoming. Soc Pet Eng. https://doi.org/10.2118/ 15098-MS

Mitchell TI, Donovan SC, Collesi JB, McSpadden HW (1984) Field application of a chemical heat and nitrogen generating system. Soc Pet Eng. https://doi.org/10.2118/12776-MS

Qamruzzaman M, Khan M, Roy DC, Raman R, Arora S (2020) Combating production loss due to paraffin deposition: a success story of thermochemical stimulation in Western India. In: Paper presented at the SPE Asia Pacific oil \& gas conference and exhibition, virtual, November 2020. https://doi.org/10.2118/202457-MS

Qian C, Wang Y, Yang Z, Qu Z, Ding M, Chen W et al (2019) A novel in situ $\mathrm{n} 2$ generation system assisted by authigenic acid for formation energy enhancement in an oilfield. RSC Adv. https://doi.org/ 10.1039/C9RA07934C

Rocha NO, Khalil CN, Leite LCF, Bastos RM (2003) A thermochemical process for wax damage removal. In: Paper presented at the international symposium on oilfield chemistry, Houston, Texas, February 2003. https://doi.org/10.2118/80266-MS

Rollins JT, Taylor LC (1959) Using heat in combination with solvents to clean up formation flow channels. Soc Pet Eng. https://doi.org/ $10.2118 / 1110-\mathrm{G}$

Saidu Mohamed A (2013) Thermo chemical in-situ heat generation technique to remove organic solid deposition: effective tool for production enhancement and flow assurance. Offshore Technol Conf. https://doi.org/10.4043/23933-MS

Shaoul JR, Ross MJ, Spitzer WJ, Wheaton SR, Mayland PJ, Singh AP (2009) Hydraulic fracturing with heated fluids brings success in high-pour-point waxy-oil reservoir in India. Soc Pet Eng. https:// doi.org/10.2118/107338-PA

Song Y, Wang J, Yu L, Zhao J (2016) Analysis of heat transfer influences on gas production from methane hydrates using a combined 
method. Int J Heat Mass Transf 92:766-773. https://doi.org/10. 1016/j.ijheatmasstransfer.2015.08.102

Tiwari S, Verma SK, Karthik R, Singh AK, Kumar S, Singh M, Kothiyal MD (2014) Insitu heat generation for near wellbore asphaltene and wax remediation. Int Pet Technol Conf. https://doi.org/10. 2523/IPTC-17681-MS

Wang Y, Li XS, Li G, Huang NS, Feng JC (2014) Experimental study on the hydrate dissociation in porous media by five-spot thermal huff and puff method. Fuel 117(1):688-696. https://doi.org/10. 1016/j.fuel.2013.09.088

White M, Pierce K, Acharya T (2018) A review of wax-formation/ mitigation technologies in the petroleum industry. SPE Prod Oper 33:476-485. https://doi.org/10.2118/189447-PA
Xie J, Hu X, Liang HZ, Wang MQ, Wang R (2020) Cold damage from wax deposition in a shallow, low-temperature, and high-wax reservoir in changchunling oilfield. Sci Rep. https://doi.org/10.1038/ s41598-020-71065-Z

Zhang K, Zhao Z, Tang M, Chen W, Li N (2020) A new type of experimentally proposed in situ heat/gas clean foam fracturing fluid system. J Pet Explor Prod Technol. https://doi.org/10.1007/ s13202-020-00983-5

Publisher's Note Springer Nature remains neutral with regard to jurisdictional claims in published maps and institutional affiliations. 